\title{
The Concept of Big Data in Bureaucratic Service Using Sentiment Analysis
}

\author{
Lia Muliawaty, Universitas Pasundan, Bandung, Indonesia \\ Kamal Alamsyah, Universitas Pasundan, Bandung, Indonesia \\ Ummu Salamah, Universitas Pasundan, Bandung, Indonesia \\ Dian Sa'adillah Maylawati, UIN Sunan Gunung Djati Bandung, Bandung, Indonesia \& Universiti Teknikal Malaysia \\ Melaka, Melaka, Malaysia
}

\begin{abstract}
The implementation of bureaucratic reform in Indonesia is not optimal and faces various obstacles. At present, public services demand excellent service and meet public satisfaction. The obstacles are rigid bureaucracy, incompetent bureaucrats or apparatuses, not professional, and there are technological gaps. Rapid technological development, such as digital technology and big data, has not been responded to positively by most bureaucrats. Big Data has a great potential for improving bureaucratic and public services. With a qualitative method and a waterfall software development life cycle, this article provides the design of a bureaucracy sentiment analysis application which implements Big Data technology for analyzing the opinions about bureaucratic service in Indonesia. This is for the purpose that the bureaucratic services can be improved based on societal opinion. The results of the experiment using RapidMiner showed that sentiment analysis as a Big Data technique for bureaucratic service based on societal opinion can be used to evaluate performance better.
\end{abstract}

\section{KEYWORDS}

Big Data, Bureaucratic Reform, Bureaucrats, Digital, New Public Service, Opinion Mining, Sentiment Analysis, Social Media, Text Mining

\section{INTRODUCTION}

Until today, there has been a stigma regarding the performance of bureaucrats and bureaucracy in various governments in the world, especially governments in developing countries such as Indonesia. Bureaucracy in many developing countries is rigid, slow, inefficient, ineffective and so on. In the midst of society, a "bad" stigma develops about bureaucracy, related to the services provided because it is still far from the expectations of society, there are "bacterial" pathologies in the body of the bureaucracy, making the image of the bureaucracy in the public eye "bad."

Therefore, the negative stigma needs to be eliminated. One way is to do bureaucratic reform. The Indonesian government carried out reforms since 1998, together with the formation of the Reform Order. Reformation is a systematic, integrated and comprehensive effort aimed at realizing good governance, including good public governance, and good corporate governance (Damanhuri, 
2017). The demands of bureaucratic reform in Indonesia occur as a result of public pressure on past government dissatisfaction (Mariana, 2017).

The fact is that bureaucratic reform in Indonesia has not been optimally implemented because of various obstacles, especially in the bureaucrats or apparatus as implementers of the policy. For example, the quality of public services that have not been optimal, is not in accordance with the criteria of the New Public Service (NPS) model. So that the level of community satisfaction is still low on services provided by the government. Some bureaucratic reforms in the aspect of public services that are the focus of attention are issues of corruption and public service and public information disclosure.

The essence of bureaucracy is its Human Resources (HR), namely bureaucrats or apparatus. HR factors that are incompetent, unprofessional, and do not master modern technology, are the weaknesses of bureaucratic reform in Indonesia. This has led to a gap between technological advances, such as digital technology and big data, with slow and less responsive bureaucracy. According to Kaloh, that work begins to change into knowledge-based work and human resource needs also change towards knowledge workers.

To improve the quality of HR in serving the community, big data technology can be used optimally, one of which is opinion mining from social media (Jumadi, Maylawati, Subaeki, \& Ridwan, 2016). Where data from social media and analyzed so as to get an analysis of community sentiment on the quality of service bureaucracy in Indonesia. Until January 2018, social media users in Indonesia reached 132.7 million out of a total population of 265.4 million (Laksana, 2018). This figure is relatively fantastic, where around 50\% of Indonesia's population owns and becomes an active social media user, starting from Twitter, Facebook, Instagram, Youtube, and so on. The smartphone is the main choice $(90 \%)$ that is used as a device to run social media applications. Based on survey results that described in Figure 1, YouTube is the most widely used social media reaching 43\%, followed by Facebook 41\%, WhatsApp 40\%, Instagram 38\%, Line 33\%, BBM 28\%, Twitter 27\%, Google+ 25\%, FB Messenger 24\%, LinkedIn 16\%, Skype 15\%, and WeChat 14\% (Haryanto, 2018). Social media users in Indonesia have a unique pattern, one of which is based on gender, men are more active using social media such as Facebook and Instagram than women for users in the age range of 18 to 24 years. Therefore, this article utilizes social media and big data technology to analyze people's sentiments and opinions about bureaucratic services in Indonesia.

Figure 1. Percentage of social media user in Indonesia

\section{PERCENTAGE OF SOCIAL MEDIA USER}

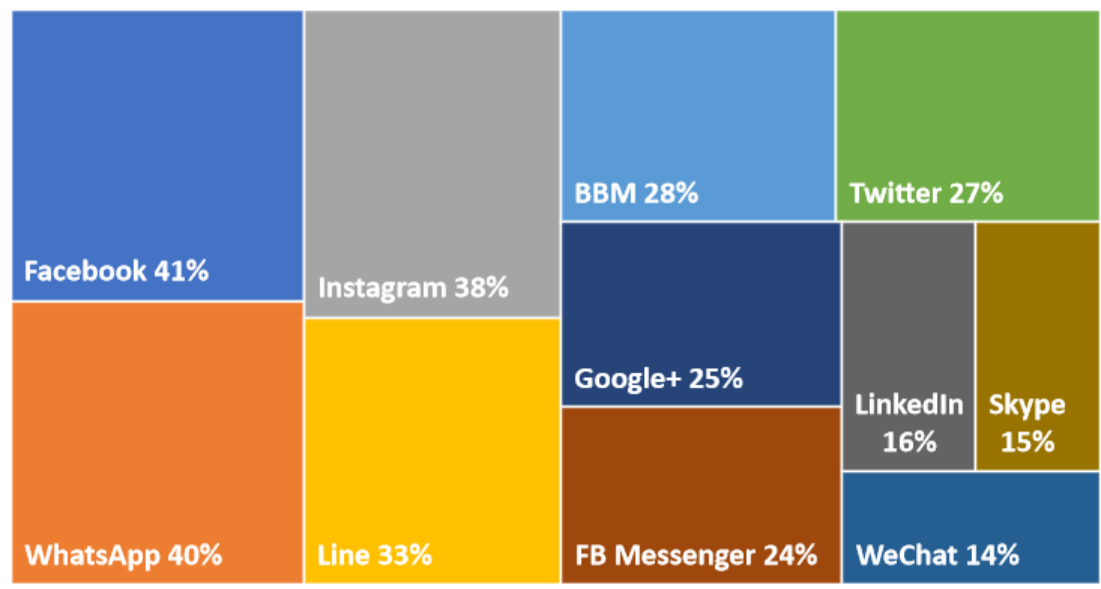




\section{RESEARCH METHOD}

This research used a qualitative method. The qualitative research method is used in the following conditions (Tracy, 2016): (a) when there is rarely any information available about the topic (b) when the researcher's variables are unclear and unknown, and (c) when a relevant theory base is missing in any sense (Tavallaei \& Abu Talib, 2010). Qualitative research can be used to examine topics such as contextual conditions-the social, institutional, and environmental conditions. Qualitative research is an inductive process which builds concepts, hypotheses, or theories rather than testing hypotheses. One of the uses of the research method delineates the process (rather than the outcome or product) of meaning-making. Qualitative research is focusing on the emergence of situations. The research methodology is a case study that has the following characteristics: particularistic, descriptive, and heuristic. A qualitative research is an inductive process which builds concepts, hypotheses, or theories rather than testing hypotheses. One of the uses of the research method delineates the process (rather than the outcome or product) of meaning-making (Sharan B. Merriam, 2009). Qualitative research is focusing on the emergence of situations. Qualitative researchers are concerned primarily with the process, rather than outcomes or products, qualitative researchers are interested in meaning how people make sense of their lives, experiences, and their structures of the world, the qualitative researcher is the primary instrument for data collection and analysis, qualitative research involves fieldwork.

Technology is developed rapidly today, so that utilizing the technology for social science will be very useful and current research (Hernandez, 2017; Moses, 2015; Nielsen, Lene Hansen, Kira Storgaard, Stage, \& Billestrup, 2015; Yeo, Zaman, \& Kulathuramaiyer, 2013). Besides the qualitative method, this research used Waterfall as the Software Development Life Cycle (SDLC). The waterfall is the basic and simple software development method that begins from requirement elicitation, analysis, design, implementation, testing, deployment, and maintenance (Ruparelia, 2010; Pressman, 2011; Sommerville, 2010). In requirement elicitation, the needs of stakeholder and system are collected (Ramdhani, Maylawati, Amin, \& Aulawi, 2018). Then, in analysis and design, we create a system model, among others architecture model and software model using Unified Modelling Language (Booch, 2005, 1998; Maylawati, Darmalaksana, \& Ramdhani, 2018; Maylawati, Ramdhani, \& Amin, 2018). In the implementing and testing phase, we used RapidMiners for analyzing the sentiment of bureaucratic service. Sentiment analysis in RapidMiners uses Deep Learning method is the development of Artificial Neural Network (ANN) method with add multiple hidden layers between input and output layer (Ahmad, Farman, \& Jan, 2019; Schmidhuber, 2015). Moreover, Deep Learning is a popular method with a various algorithm in text analytics research today.

From the explanation above, in this research, qualitative methods are combined with SDLC and Big Data Technology for sentiment analysis from social media. Figure 2 describes about flow activity of research methodology. In requirement, elicitation is implemented a qualitative method with analyzing the phenomena, facts, and condition of bureaucracy in Indonesia. Then, besides collecting the related literature studies, the data from social media are also collected and analyzed that used as an input requirement of sentiment analysis system. Therefore, this is one of the differences with the research before combining information technology techniques and social science.

\section{RESULT AND DISCUSSION}

\section{The Performance of Bureaucrats in the Digital Age}

Bureaucracy is a device/ institution of employees/ HR and a system of government administration carried out by civil servants based on legislation (Damanhuri., 2017). Bureaucracy is a storage place for typical and unique public trust. "In general, the term 'bureaucracy' is regarded as having a negative connotation, although there have been anarchists that enjoyed the excess of formalism and rigor" (Liviora, 2018). There are three bureaucratic concepts, namely (Mariana, 2017) 2) The Concept of Parkinson Law; and 3) Ovulation Concept (2017, p. 93). Bureaucracy is characterized by hierarchy, 


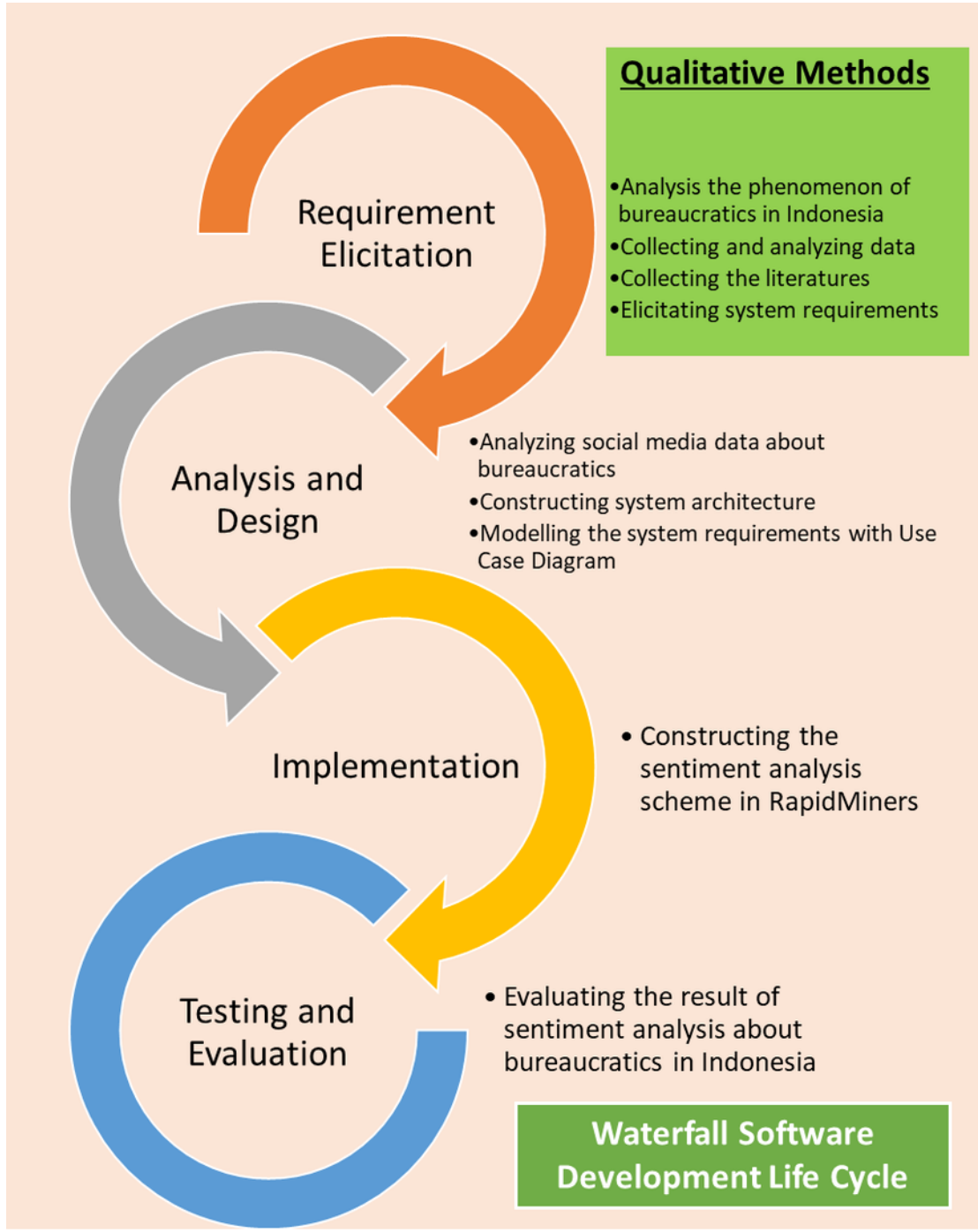

specialization, formalization, and impersonality (Widiyastuti, Andretti Abdillah, \& Kurniawan, 2014). Bureaucracy only emphasizes how the bureaucratic machine should be professionally and rationally run. Furthermore, bureaucracy shows a lot about how government organizations are adopted by means of official kingdoms. The bureaucratic model currently being implemented does not show a system that represents the nature of justice, transparency, and efficiency (Sanrego Nz \& Muhammad, 2013).

Social media is one of the characteristics of technological development in the era of Industry 4.0. In the Industrial 4.0 era, where everything is connected to internet technology (internet of things) (Kemeristekdikti, 2018; Nizam, 2018; Sadiyoko, 2017). Where industry 4.0 is characterized by internet usage in each sector, both in the economy, social, education, and other sectors. The entire process and production utilizes internet technology and utilizes digital technology, artificial intelligence, big data, robotics, etc. which are also known as the disruptive innovation phenomenon (Office of Chief Economist Bank Mandiri, 2018; Sumber Daya: Iptek \& Dikti, 2018). Big data is a very large set of data that can be computationally analyzed to find patterns, trends, associations, and specifically, those 
related to habits and human interactions (Chen \& Zhang, 2014; Sagiroglu \& Sinanc, 2013; Wu, Zhu, $\mathrm{Wu}, \&$ Ding, 2014). In analyzing social media, of course, big data technology is needed, considering that data in the media has big data characteristics. At the beginning of its appearance, big data only has $3 \mathrm{~V}$ characteristics, including volume, variety, and velocity (Sagiroglu \& Sinanc, 2013; Tan, Blake, Saleh, \& Dustdar, 2013). However, there are currently at least $10 \mathrm{~V}, 17 \mathrm{~V}$, up to more, including volume, velocity, variety, veracity, value, validity, variability, venue, vocabulary, vagueness, visualization, etc. (Arockia, Varnekha, \& Veneshia, 2017; Borne, 2014). Social media that has various types of data such as text, images and videos is very suitable if processed with big data technology. Various big data applications are ready to use to process and analyze data from social media to reveal insight knowledge from the data (Panatula, Kumar, \& Geetha, 2019; Vinutha \& Raju, 2018).

The discovery of computer technology is a big leap of human civilization on earth that drives other discoveries, such as digital technology. The digital age is a new paradigm in the government bureaucracy in Indonesia, including the public service sector. This paradigm is an important and radical transition from New Public Management (NPM) towards a digital governance model (Kosorukov, 2017). Most governments in the regions have not been able to implement bureaucratic digitalization because of various factors, including large costs and qualifications of human resources who master technology are still minimal. Although there are exceptions to the cities of Bandung and Banyuwangi which are considered capable of applying modern technology.

Through the use of digital devices (e-government), public services are more efficient, effective, fast, and accurate (Pamoragung, Suryadi, \& Ramdhani, 2006). So that bureaucratic procedures are more practical and brief. Similarly, through digitalization, the number of operational officers can be reduced but the number of services can be increased (Ramdhani, Aulawi, \& Gojali, 2018). Previously, the process of public services such as health services, education, licensing, etc., took a long time/ took a long time. Besides that, direct interaction between bureaucrats or apparatus can encourage acts of corruption and the like.

Rapid technological developments have caused previous technologies to become unused or obsolete, such as hardware or computer software. In addition, it has a direct impact on its users, namely the bureaucrats and apparatus must improve their knowledge and skills with these new devices. If not done it can cause their performance to be unproductive and the level of community satisfaction low. Public services require the involvement of many actors because their implementation is related to many actors. Faulkner also explained the need for cooperation in implementing public services. Government Leadership and Public Services can be generated and sustained a sense of shared purpose and responsibility.

\section{Big Data: A New Paradigm, Challenges, and Constraints}

Big Data can be used by all parties and sectors, including government. For example, for the provision of health services, education, and improving the quality of the bureaucracy and its bureaucrats. The use of big data is important for improving the quality of public services, especially associated with modern developments that require many aspects, including excellent service quality and speed of service processes. At present, the public policy model adopts many services provided by the private sector in order to fulfill public satisfaction as service users. Through big data, policies or programs can be designed appropriately, efficiently and effectively. So far, Big Data has been used by large private companies in improving product quality, developing markets, and choosing the right marketing techniques. Big Data provides accurate data so that programs designed using big data have high accuracy and are economical. Big Data has a variety of data and large so that it is just how to process and use these data for interest.

But Big Data cannot be accessed or processed with traditional devices because of the huge amount of data and many variants. So to access it requires the latest technology. This is an obstacle for some companies and governments in utilizing the potential of Big Data. As is known, most governments are held in a limited and less optimal manner. The limitations of technology-based work devices have 
caused the minimal quality of public services, low bureaucrat work productivity, rigid bureaucratic procedures, and non-optimal results.

This is caused by a variety of factors, including the quality of human resources (HR) and their working devices. Only a few local governments are able to provide the latest technology-based work tools because these facilities are expensive and require professional HR. Knowledge-based works require knowledge of workers. The change in work orientation is a new paradigm and challenges and obstacles for bureaucrats in carrying out efficient and effective bureaucracy. The criteria for efficient and effective bureaucracy is the absolute demand in modern government, namely in order to provide quality and optimal public services.

\section{Sentiment Analysis Architecture as Big Data Technology for Bureaucratic}

The data from social media that is the easiest to process is text. Text is the unstructured data, so that it must be conducted the pre-process until the text data ready to be processed in mining process (Maylawati, Sugilar, \& Yudhiantara, 2018; Maylawati, Ramdhani, Rahman, \& Darmalaksana, 2017; Maylawati \& Saptawati, 2017; Slamet et al., 2018). In the requirement elicitation phase, we defined several requirements of bureaucracy sentiment analyzer application, among others:

1. The application can read the corpus that contains document from social media, such as Twitter, Facebook, or blog and news website;

2. The application can do text pre-processing, such as lowercase, tokenizing, emoticon handling, abbreviation handling, a regular expression (regex) removal, stopwords removal, and stemming;

3. The application can conduct feature extraction, either bag of words or multiple words (n-gram);

4. The application can conduct feature selection, such as removing redundant;

5. The application can do the mining process with a classification technique for sentiment analysis using a specific algorithm, such as the Naive Bayes algorithm, Decision Tree, Artificial Neural Network, and so on. Where in the mining process there are two main processes in classification, among others training process and testing process;

6. The application provides the result of bureaucracy sentiment analysis.

Figure 3 describes the bureaucracy sentiment analyzer architecture, while Figure 4 describes the use case diagram of bureaucracy sentiment analyzer which is representation model of analysis in Waterfall SDLC after requirement elicitation.

Figure 3. Bureaucracy sentiment analyzer architecture

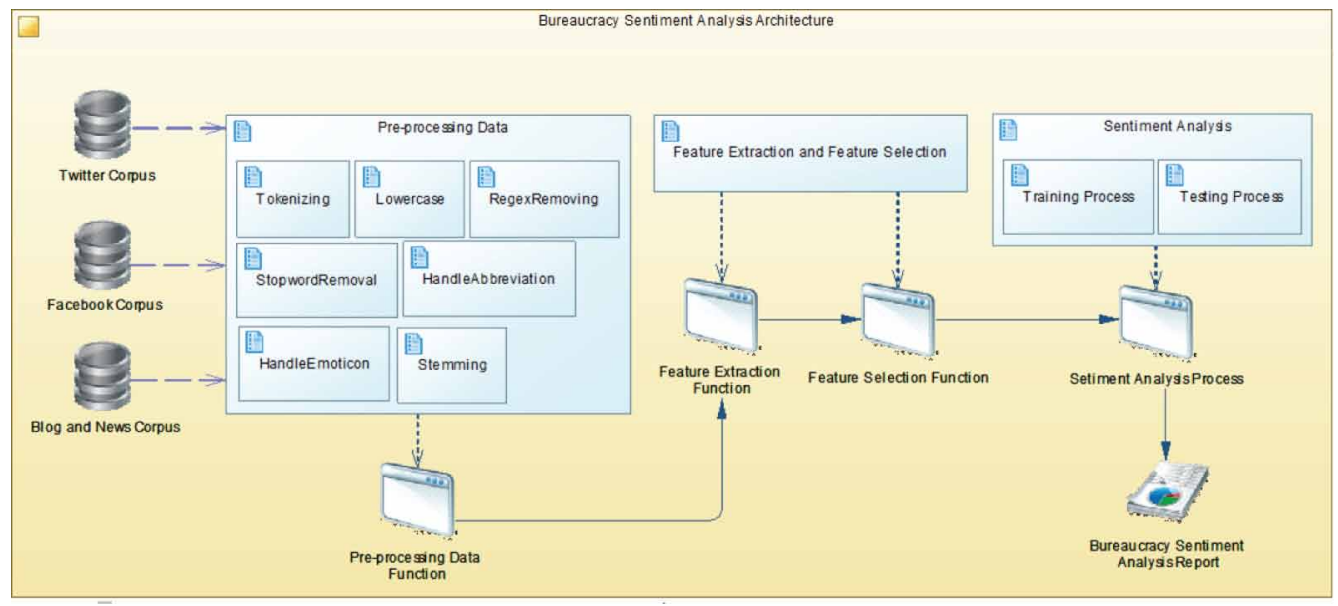




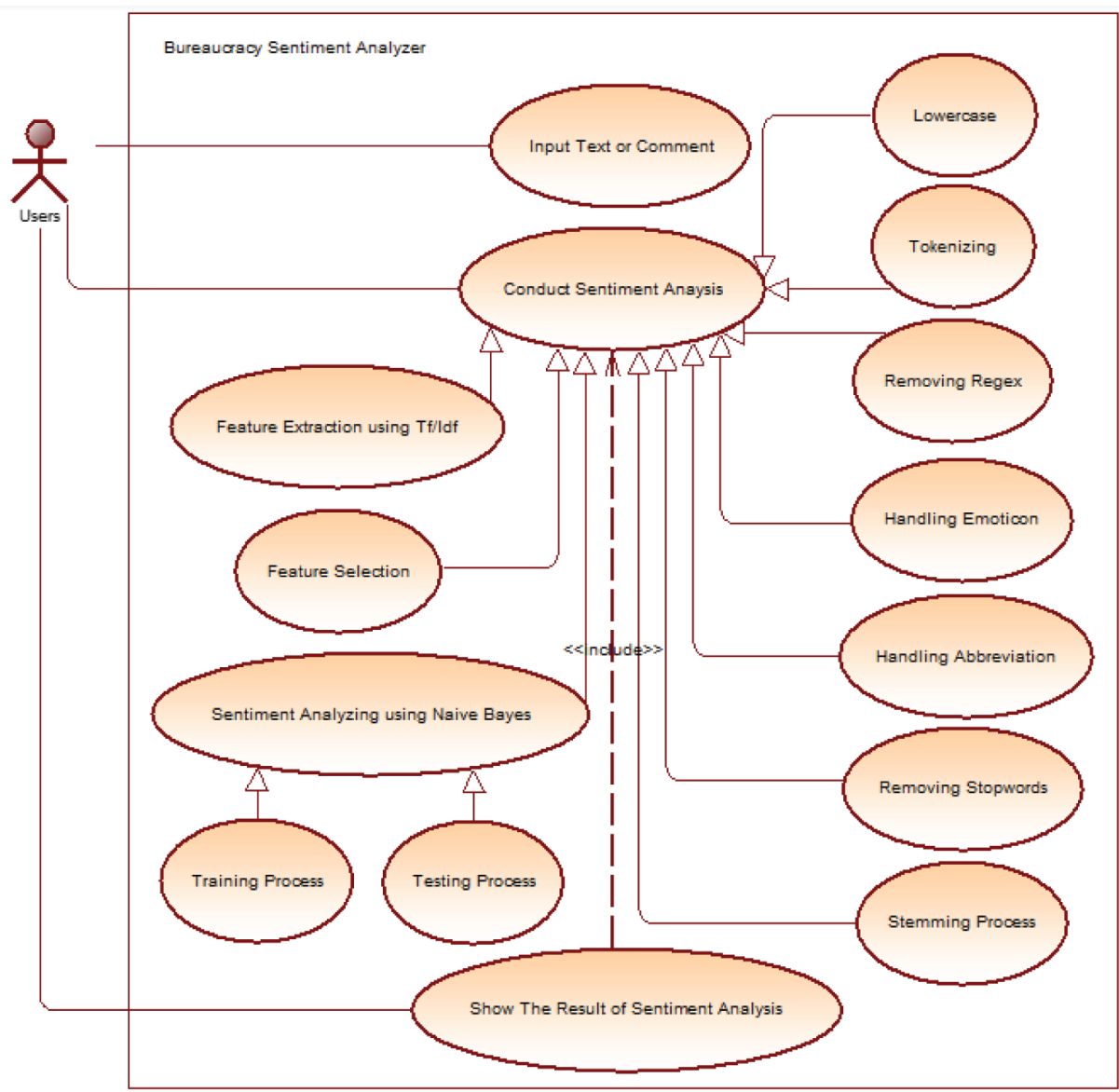

\section{The Example of Sentiment Analysis Application}

Many data mining tools as big data technique that can be used easily, one of which is RapidMiner (Studio, n.d.). This article used RapidMiner as the implementation example for analyzing the sentiment of bureaucrats and bureaucracy service in Indonesia. Figures 5-8 shows the process scheme of bureaucracy sentiment analysis in RapidMiner. In RapidMiner there are many text analytic extensions that can be used easily, among others Aylien (Aylien, n.d.) and Rosette (Rosette, n.d.). All of the text mining or text analytic process has been included in its functions so that we just combine the function in the process and run it. We collect the data from Twitter with the keyword "bureaucracy" and "birokrasi". Sentiment analysis from text data depends on the language. Every language is unique and has different treatment to get clean data and accurate result (Maylawati, 2015; Maylawati, Aulawi, \& Ramdhani, 2019; Maylawati, Zulfikar, Slamet, \& Ramdhani, 2018; Maylawati \& Saptawati, 2017), and RapidMiner is limited to English, German, French, Czech, and Arabic. For another language, RapidMiner provides a general function to insert the dictionary and process it.

Figure 5-8 also describes the result of bureaucracy sentiment analysis from Twitter directly. Figure 5 shows the result of bureaucracy sentiment analysis using Aylien, from 100 tweets from Twitter, 62 tweets have a positive opinion, 32 tweets are negative, and 6 tweets are neutral. While, the result using Rosette quite different (with the same data collection and illustrated in Figure 6), where positive tweets are 21, 40 tweets are negative, and 39 tweets are neutral-. Even though there are different in 
Figure 5. The result of Aylien for bureaucracy sentiment analysis

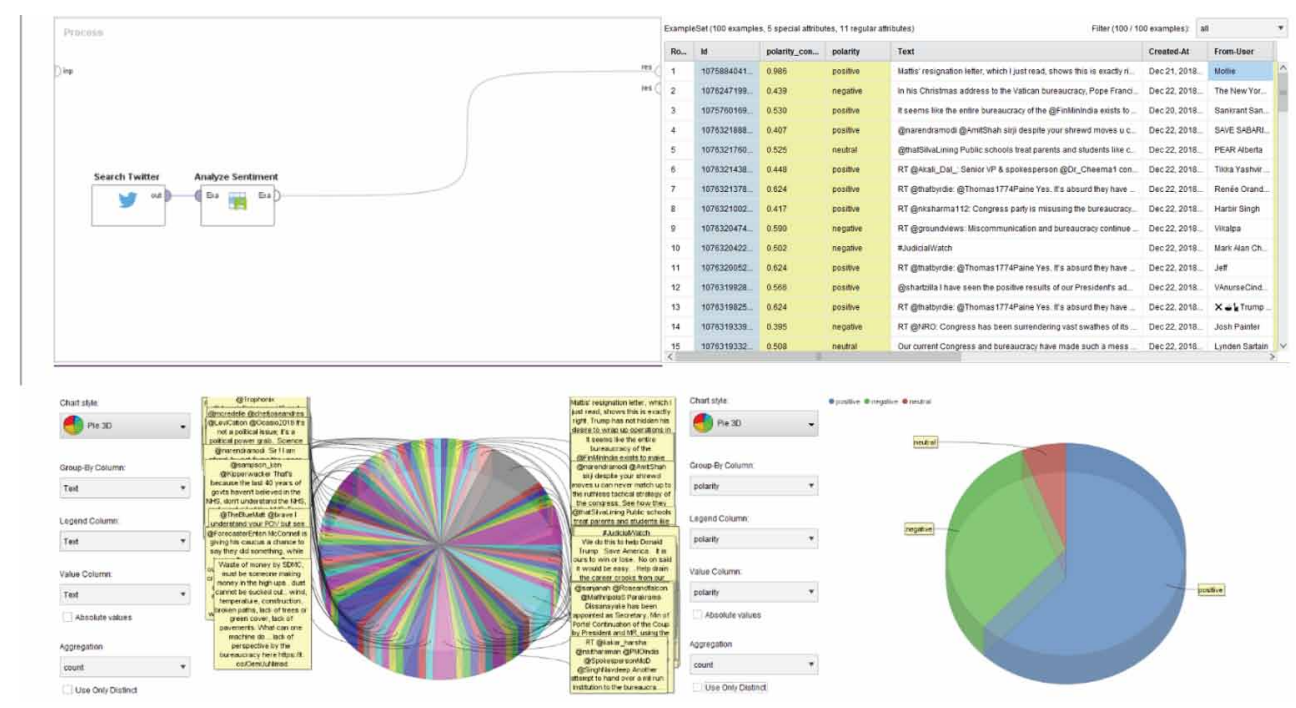

Figure 6. The result of Rosette for bureaucracy sentiment analysis

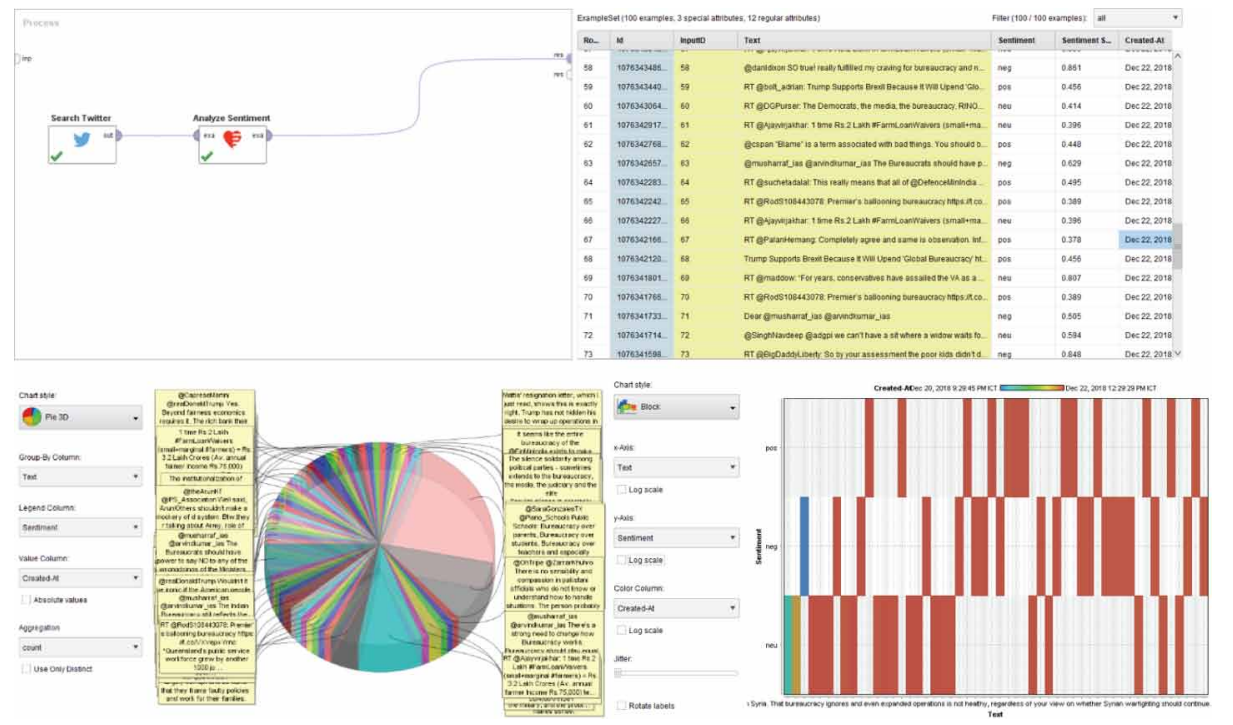

classifying the sentiment, but the important thing is from that experiment (with 100 tweets) around $41.5 \%$ the opinions about bureaucratic service are positive, around 36\% are negative opinion, and around $22.5 \%$ are neutral opinion. It means that the community feels quite satisfied with bureaucratic services, although those who have a positive and neutral opinion are not too much different. However, it remains to be noted that there are also many who think negatively about the existing bureaucratic services. This result can be used as an evaluation material for things that are not suitable, not good so that the community is not satisfied and has a negative opinion on bureaucratic services.

We also collect 200 tweets with the Indonesian language for analyzing the sentiment about bureaucracy in Indonesia. The result of Aylien in Figure 7 shows that only 3 tweets that have a positive 
Figure 7. The result of Aylien for bureaucracy sentiment analysis with Indonesian text

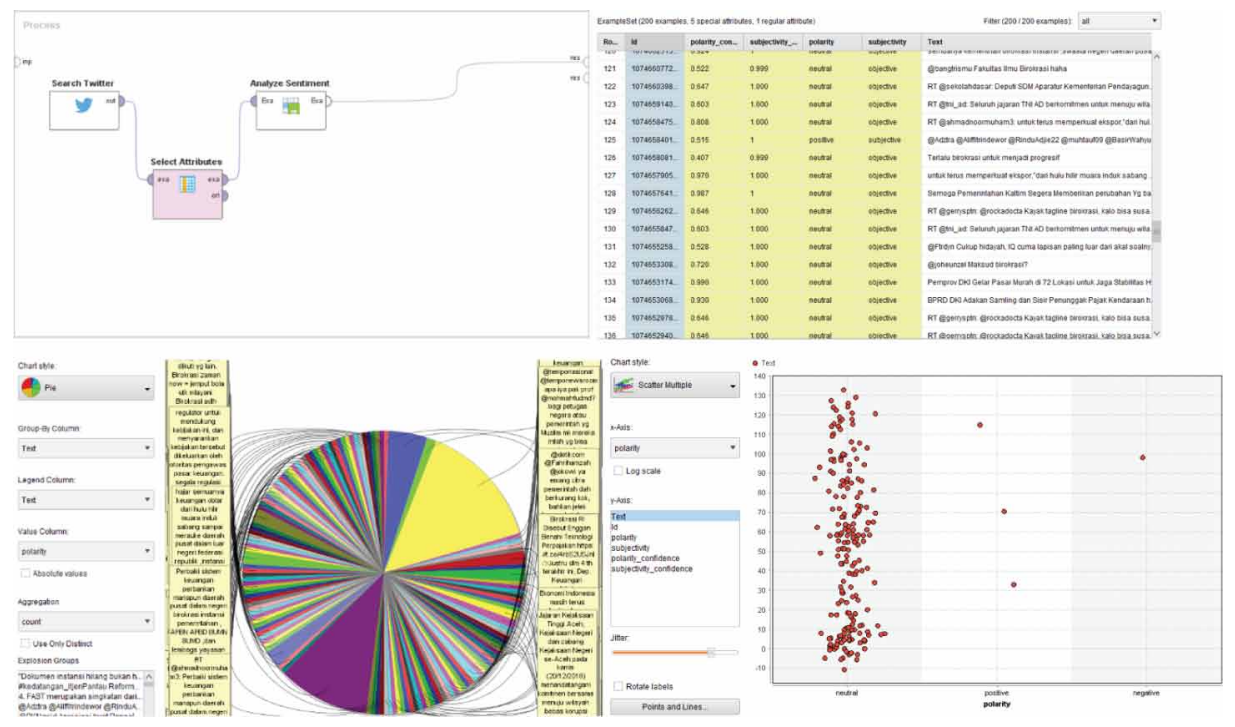

Figure 8. The result of Rosette for bureaucracy sentiment analysis with Indonesian text

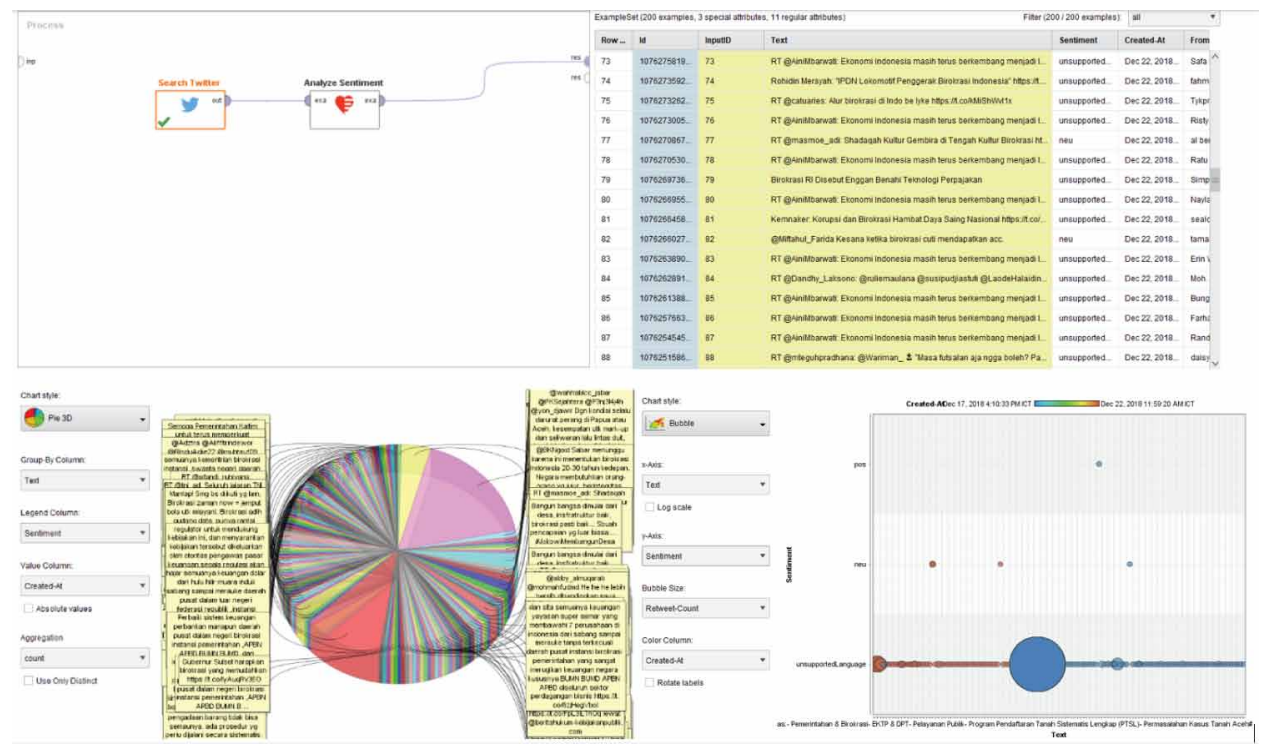

opinion, 1 tweet is negative, and 196 tweets are neutral. While the result using Rosette in Figure 8 shows that 1 tweet is detected has a positive opinion, 0 for the negative tweet, 5 for neutral tweets and 194 tweets for unsupported language. The results of sentiment analysis with Indonesian text in RapidMiner have not been capable yet to be used to analyze the public opinion about bureaucracy in Indonesia, because-it is constrained by language processing that has not been supported by RapidMiner. Those result can be used as an illustration of how the public opinion about bureaucracy. Besides that, the process in RapidMiner is an implementation illustration of sentiment analysis process as big data technique that has been provided in architecture and use case diagram above (in Figure 3 
and 4). The main idea is big data technology can be used to improve bureaucracy service based on society or public opinions.

\section{CONCLUSION}

Bureaucratic reform in most regional governments has not yet materialized. This causes the quality of public services is not optimal and public satisfaction is low. Therefore, the reform process needs to be accelerated. The main obstacle in realizing bureaucracy in accordance with good governance is its human resources, namely bureaucrats. Most bureaucrats are unprofessional, do not have the expertise that is in accordance with the field and work responsibilities. So that the performance of bureaucrats is not optimal. Another obstacle is the factor of working facilities or working devices that are limited and simple. While, the demands of the modern bureaucracy are work devices based on modern technology, such as digital technology. Big data can be utilized by regional government bureaucracies because of the two main factors above, namely bureaucrats and modern technological devices. So that the potential for big data can be used optimally. This article success to design a sentiment analysis architecture and functional model as big data technology for bureaucracy opinion in social media. The experiment proved that the result of sentiment can be used as information to evaluate, to make a decision, and to improve bureaucracy service quality. 


\section{REFERENCES}

Ahmad, J., Farman, H., \& Jan, Z. (2019). Deep Learning Methods and Applications. In Deep Learning: Convergence to Big Data Analytics (pp. 31-42). Springer. doi:10.1007/978-981-13-3459-7_3

Arockia, P. S., Varnekha, S. S., \& Veneshia, K. A. (2017). The 17 V's of Big Data. International Research Journal of Engineering and Technology, 4(9), 3-6. Retrieved from https://irjet.net/archives/V4/i9/IRJET-V4I957.pdf

Aylien. (n.d.). Aylien Text Analytics. Retrieved from https://aylien.com/

Booch, G. (1998). Object-Oriented Analysis and Design (2nd ed.). Santa Clara, CA: Addison-Wesley.

Booch. (2005). The Unified Modeling Language User Guide. Addison-Wesley. Retrieved from http://books. google.com/books?id=xfQ8JCbxDK8C\&pgis=1

Borne, K. (2014). Top 10 List - The V's of Big Data. Data Science Central. Retrieved from https://www. datasciencecentral.com/profiles/blogs/top-10-list-the-v-s-of-big-data

Damanhuri, J. R. (2017). Reaktualisasi reformasi birokrasi menuju good governance. In Prosiding Seminar Nasional Pendidikan FKIP (pp. 297-304).

Haryanto, A. T. (2018). 130 Juta Orang Indonesia Tercatat Aktif di Medsos. Retrieved from https://inet.detik. com/cyberlife/d-3912429/130-juta-orang-indonesia-tercatat-aktif-di-medsos

Hernandez, A. A. (2017). Green IT Adoption Practices in Education Sector : A Developing Country Perspective. International Journal of Sociotechnology and Knowledge Development (IJSKD). doi:10.4018/IJSKD.2017070101

Jumadi, M., D. S. A., Subaeki, B., \& Ridwan, T. (2016). Opinion mining on Twitter microblogging using Support Vector Machine: Public opinion about State Islamic University of Bandung. In Proceedings of 2016 4th International Conference on Cyber and IT Service Management, CITSM 2016. Academic Publisher. doi:10.1109/ CITSM.2016.7577569

Kemeristekdikti. (2018). Pengembangan Iptek dan Pendidikan Tinggi di Era Revolusi Industri 4.0.

Kosorukov, A. A. (2017). Digital government model: Theory and practice of modern public administration. Journal of Legal, Ethical \& Regulatory Issues.

Laksana, N. C. (2018). Ini Jumlah Total Pengguna Media Sosial di Indonesia. Retrieved from https://techno. okezone.com/read/2018/03/13/207/1872093/ini-jumlah-total-pengguna-media-sosial-di-indonesia

Liviora, G., G. (2018). Bureaucratic administration in modern society.

Mariana, D. (2017). Aparatur sipil negara dan reformasi birokrasi. Jurnal Ilmu Politik, 22(1), 91-104.

Maylawati, D. S., Aulawi, H., \& Ramdhani, M. A. (2019). Flexibility of Indonesian text pre-processing library. Indonesian Journal of Electrical Engineering and Computer Science, 13(1), 420-426. doi:10.11591/ijeecs. v13.11.pp420-426

Maylawati, D. S., Darmalaksana, W., \& Ramdhani, M. A. (2018). Systematic Design of Expert System Using Unified Modelling Language. IOP Conference Series. Materials Science and Engineering, 288(1), 012047. doi:10.1088/1757-899X/288/1/012047

Maylawati, D. S., Ramdhani, M. A., \& Amin, A. S. (2018). Tracing the Linkage of Several Unified Modelling Language Diagrams in Software Modelling Based on Best Practices. International Journal of Engineering \& Technology, 7(2.29), 776-780. doi:10.14419/ijet.v7i2.29.14255

Maylawati, D. S., Ramdhani, M. A., Rahman, A., \& Darmalaksana, W. (2017). Incremental technique with set of frequent word item sets for mining large Indonesian text data. In Proceedings of the 2017 5th International Conference on Cyber and IT Service Management CITSM 2017 (pp. 1-6). Academic Publisher. doi:<ALIGNMENT.qj></ALIGNMENT>10.1109/CITSM.2017.8089224

Maylawati, D. S., Sugilar, H., \& Yudhiantara, R. A. (2018). Kualitas perangkat lunak: Modularitas pustaka text pre-processing. Jurnal Perspektif, 1(2). 
Maylawati, D. S., Zulfikar, W. B., Slamet, C., \& Ramdhani, M. A. (2018). An Improved of Stemming Algorithm for Mining Indonesian Text with Slang on Social Media. In Proceedings of the 6th International Conference on Cyber and IT Service Management (CITSM 2018). Academic Publisher. doi:10.1109/CITSM.2018.8674054

Maylawati, D. S. A. (2015). Pembangunan Library pre-processing untuk text mining dengan representasi himpunan frequent word itemset (HFWI) Studi Kasus: Bahasa Gaul Indonesia. Bandung.

Merriam, S. B. (2009). Qualitative Research: A Guide to Design and Implementation. Wiley. doi:10.1017/ CBO9781107415324.004

Moses, J. A. (2015). A project management approach to learning. International Journal of Sociotechnology and Knowledge Development.

Muhammad Nizam, S. (2018). Revolusi industri 4.O: Suatu Pengenalan. Seranta FELDA Jabatan Perdana Menteri.

Nielsen, L. H., \& Storgaard, K., Stage, J., \& Billestrup, J. (2015). A Template for Design Personas: Analysis of 47 Persona Descriptions from Danish Industries and Organizations. International Journal of Sociotechnology and Knowledge Development. doi:10.4018/ijskd.2015010104

Office of Chief Economist Bank Mandiri. (2018). Menghadapi Era RI 4.0.

Pamoragung, A., Suryadi, K., \& Ramdhani, M. A. (2006). Enhancing the Implementation of E-Government in Indonesia through the High-Quality of Virtual Community and Knowledge Portal Design. In Proceedings of the European Conference on e-Government (pp. 341-348).

Panatula, K., G., , Kumar, D., S., , Geetha, T. V. S. K., \& E. , (2019). Performance evaluation of cloud service with hadoop for twitter data. Indonesian Journal of Electrical Engineering and Computer Science, 13(1).

Philip Chen, C. L., \& Zhang, C. Y. (2014). Data-intensive applications, challenges, techniques and technologies: A survey on Big Data. Information Sciences, 275, 314-347. doi:10.1016/j.ins.2014.01.015

Pressman, R. S. (2011). Software Engineering: A Practitioner's Approach (7th ed.). New York: McGraw-Hill.

Ramdhani, M. A., Aulawi, H., \& Gojali, D. (2018). Analysis of determinant factors of e-Government implementation. IOP Conference Series. Materials Science and Engineering, 434, 12049. doi:10.1088/1757$899 \mathrm{X} / 434 / 1 / 012049$

Ramdhani, M. A., Sa'adillah Maylawati, D., Amin, A. S., \& Aulawi, H. (2018). Requirements Elicitation in Software Engineering. IACSIT International Journal of Engineering and Technology. doi:10.14419/ijet. v7i2.29.14254

Rosette. (n.d.). Rosette Text Analytics. Retrieved from https://www.rosette.com/

Ruparelia, N. B. (2010). Software Development Lifecycle Models. Software Engineering Notes, 35(3), 8. doi:10.1145/1764810.1764814

Sa'Adillah Maylawati, D., \& Putri Saptawati, G. A. (2017). Set of Frequent Word Item sets as Feature Representation for Text with Indonesian Slang. In Journal of Physics (Vol. 801). Conference Series; doi:10.1088/1742-6596/801/1/012066

Sa'Adillah Maylawati, D., \& Putri Saptawati, G. A. (2017). Set of Frequent Word Item sets as Feature Representation for Text with Indonesian Slang. Journal of Physics: Conference Series, 801(1). doi:10.1088/17426596/801/1/012066

Sadiyoko, A. (2017). Industry 4.0 Ancaman, Tantangan atau Kesempatan. Oratio Dies XXIV FTI UNPAR.

Sagiroglu, S., \& Sinanc, D. (2013). Big data: A review. In Proceedings of the 2013 International Conference on Collaboration Technologies and Systems, CTS 2013. Academic Press. doi:10.1109/CTS.2013.6567202

Sanrego Nz, Y. D., \& Muhammad, R. (2013). Analisa perbandingan model birokrasi Indonesia: Model modern David Osborne, Ted Gaebler dan pendekatan konsep Islam perspektif Umer Chapra. Jurnal Al-Muzara'ah, $1(1), 18-38$.

Schmidhuber, J. (2015). Deep Learning in neural networks: An overview. Neural Networks, 61, 85-117. doi:10.1016/j.neunet.2014.09.003 PMID:25462637 
Slamet, C., Atmadja, A. R., Maylawati, D. S., Lestari, R. S., Darmalaksana, W., \& Ramdhani, M. A. (2018). Automated Text Summarization for Indonesian Article Using Vector Space Model. In Proceedings of the IOP Conference Series: Materials Science and Engineering. doi:10.1088/1757-899X/288/1/012037

Sommerville, I. (2010). Software Engineering. In Software Engineering. doi:10.1111/j.1365-2362.2005.01463.x Rapidminer Studio. (n.d.). RapidMiner. Retrieved from https://rapidminer.com/

Sumber Daya: Iptek \& Dikti. (2018). Era Revolusi Industri 4.0 Saatnya Generasi Millenial Menjadi Dosen Masa Depan.

Tan, W., Blake, M. B., Saleh, I., \& Dustdar, S. (2013). Social-network-sourced big data analytics. IEEE Internet Computing, 17(5), 62-69. doi:10.1109/MIC.2013.100

Tavallaei, M., \& Talib, M. A. (2010). A general perspective on role of theory in qualitative research. Journal of International Social Research, 3(11).

Tracy, J. S. (2016). Qualitative Research Methods. United Kingdom: Wiley-Blackwell.

Vinutha, D. \& Raju, G.T. (18AD). An Accurate and Efficient Scheduler for Hadoop MapReduce Framework. Indonesian Journal of Electrical Engineering and Computer Science 2, 12(3).

Widiyastuti, S., Abdillah, L.A., \& Kurniawan. (2014). Sistem Informasi Eksekutif Bagian Kepegawaian Pada Pt. Pelindo Ii (Persero) Palembang. Seminar Nasional Teknologi Informasi, Komunikasi Dan Manajemen.

Wu, X., Zhu, X., Wu, G. Q., \& Ding, W. (2014). Data mining with big data. IEEE Transactions on Knowledge and Data Engineering. doi:10.1109/TKDE.2013.109

Yeo, A. W., Zaman, T., \& Kulathuramaiyer, N. (2013). Indigenous Knowledge Management in the Kelabit Community in Eastern Malaysia: Insights and Reflections for Contemporary KM Design. International Journal of Sociotechnology and Knowledge Development, 5(1), 23-36. doi:10.4018/jskd.2013010103 


\title{
The Concept of Big Data in Bureaucratic Service Using Sentiment Analysis
}

\author{
Lia Muliawaty, Universitas Pasundan, Bandung, Indonesia \\ Kamal Alamsyah, Universitas Pasundan, Bandung, Indonesia \\ Ummu Salamah, Universitas Pasundan, Bandung, Indonesia \\ Dian Sa'adillah Maylawati, UIN Sunan Gunung Djati Bandung, Bandung, Indonesia \& Universiti Teknikal Malaysia \\ Melaka, Melaka, Malaysia
}

\begin{abstract}
The implementation of bureaucratic reform in Indonesia is not optimal and faces various obstacles. At present, public services demand excellent service and meet public satisfaction. The obstacles are rigid bureaucracy, incompetent bureaucrats or apparatuses, not professional, and there are technological gaps. Rapid technological development, such as digital technology and big data, has not been responded to positively by most bureaucrats. Big Data has a great potential for improving bureaucratic and public services. With a qualitative method and a waterfall software development life cycle, this article provides the design of a bureaucracy sentiment analysis application which implements Big Data technology for analyzing the opinions about bureaucratic service in Indonesia. This is for the purpose that the bureaucratic services can be improved based on societal opinion. The results of the experiment using RapidMiner showed that sentiment analysis as a Big Data technique for bureaucratic service based on societal opinion can be used to evaluate performance better.
\end{abstract}

\section{KEYWORDS}

Big Data, Bureaucratic Reform, Bureaucrats, Digital, New Public Service, Opinion Mining, Sentiment Analysis, Social Media, Text Mining

\section{INTRODUCTION}

Until today, there has been a stigma regarding the performance of bureaucrats and bureaucracy in various governments in the world, especially governments in developing countries such as Indonesia. Bureaucracy in many developing countries is rigid, slow, inefficient, ineffective and so on. In the midst of society, a "bad" stigma develops about bureaucracy, related to the services provided because it is still far from the expectations of society, there are "bacterial" pathologies in the body of the bureaucracy, making the image of the bureaucracy in the public eye "bad."

Therefore, the negative stigma needs to be eliminated. One way is to do bureaucratic reform. The Indonesian government carried out reforms since 1998, together with the formation of the Reform Order. Reformation is a systematic, integrated and comprehensive effort aimed at realizing good governance, including good public governance, and good corporate governance (Damanhuri, 
2017). The demands of bureaucratic reform in Indonesia occur as a result of public pressure on past government dissatisfaction (Mariana, 2017).

The fact is that bureaucratic reform in Indonesia has not been optimally implemented because of various obstacles, especially in the bureaucrats or apparatus as implementers of the policy. For example, the quality of public services that have not been optimal, is not in accordance with the criteria of the New Public Service (NPS) model. So that the level of community satisfaction is still low on services provided by the government. Some bureaucratic reforms in the aspect of public services that are the focus of attention are issues of corruption and public service and public information disclosure.

The essence of bureaucracy is its Human Resources (HR), namely bureaucrats or apparatus. HR factors that are incompetent, unprofessional, and do not master modern technology, are the weaknesses of bureaucratic reform in Indonesia. This has led to a gap between technological advances, such as digital technology and big data, with slow and less responsive bureaucracy. According to Kaloh, that work begins to change into knowledge-based work and human resource needs also change towards knowledge workers.

To improve the quality of HR in serving the community, big data technology can be used optimally, one of which is opinion mining from social media (Jumadi, Maylawati, Subaeki, \& Ridwan, 2016). Where data from social media and analyzed so as to get an analysis of community sentiment on the quality of service bureaucracy in Indonesia. Until January 2018, social media users in Indonesia reached 132.7 million out of a total population of 265.4 million (Laksana, 2018). This figure is relatively fantastic, where around 50\% of Indonesia's population owns and becomes an active social media user, starting from Twitter, Facebook, Instagram, Youtube, and so on. The smartphone is the main choice $(90 \%)$ that is used as a device to run social media applications. Based on survey results that described in Figure 1, YouTube is the most widely used social media reaching 43\%, followed by Facebook 41\%, WhatsApp 40\%, Instagram 38\%, Line 33\%, BBM 28\%, Twitter 27\%, Google+ 25\%, FB Messenger 24\%, LinkedIn 16\%, Skype 15\%, and WeChat 14\% (Haryanto, 2018). Social media users in Indonesia have a unique pattern, one of which is based on gender, men are more active using social media such as Facebook and Instagram than women for users in the age range of 18 to 24 years. Therefore, this article utilizes social media and big data technology to analyze people's sentiments and opinions about bureaucratic services in Indonesia.

Figure 1. Percentage of social media user in Indonesia

\section{PERCENTAGE OF SOCIAL MEDIA USER}

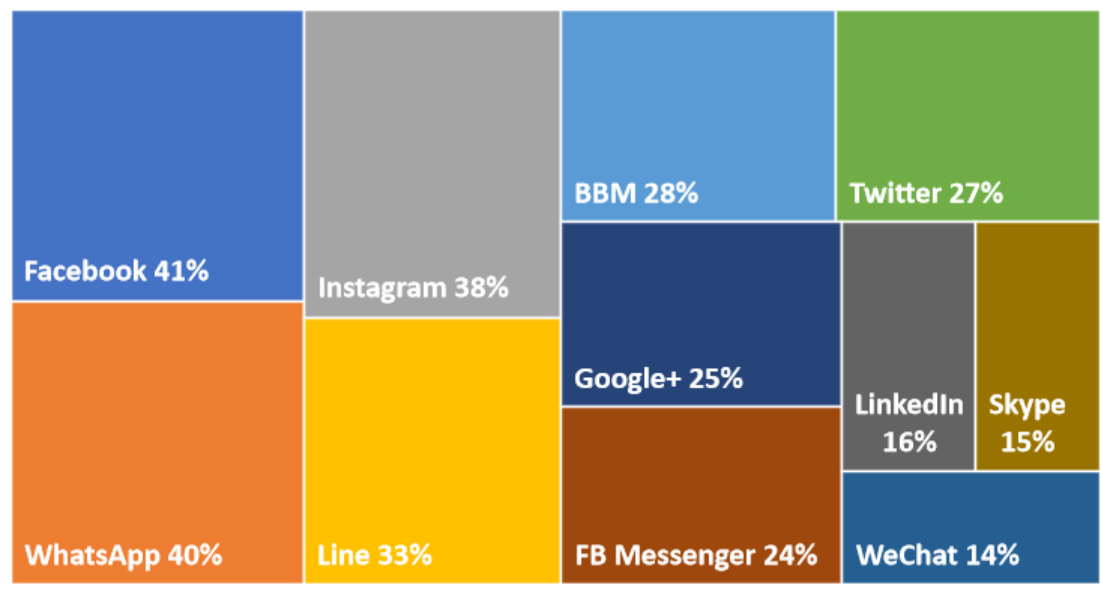




\section{RESEARCH METHOD}

This research used a qualitative method. The qualitative research method is used in the following conditions (Tracy, 2016): (a) when there is rarely any information available about the topic (b) when the researcher's variables are unclear and unknown, and (c) when a relevant theory base is missing in any sense (Tavallaei \& Abu Talib, 2010). Qualitative research can be used to examine topics such as contextual conditions-the social, institutional, and environmental conditions. Qualitative research is an inductive process which builds concepts, hypotheses, or theories rather than testing hypotheses. One of the uses of the research method delineates the process (rather than the outcome or product) of meaning-making. Qualitative research is focusing on the emergence of situations. The research methodology is a case study that has the following characteristics: particularistic, descriptive, and heuristic. A qualitative research is an inductive process which builds concepts, hypotheses, or theories rather than testing hypotheses. One of the uses of the research method delineates the process (rather than the outcome or product) of meaning-making (Sharan B. Merriam, 2009). Qualitative research is focusing on the emergence of situations. Qualitative researchers are concerned primarily with the process, rather than outcomes or products, qualitative researchers are interested in meaning how people make sense of their lives, experiences, and their structures of the world, the qualitative researcher is the primary instrument for data collection and analysis, qualitative research involves fieldwork.

Technology is developed rapidly today, so that utilizing the technology for social science will be very useful and current research (Hernandez, 2017; Moses, 2015; Nielsen, Lene Hansen, Kira Storgaard, Stage, \& Billestrup, 2015; Yeo, Zaman, \& Kulathuramaiyer, 2013). Besides the qualitative method, this research used Waterfall as the Software Development Life Cycle (SDLC). The waterfall is the basic and simple software development method that begins from requirement elicitation, analysis, design, implementation, testing, deployment, and maintenance (Ruparelia, 2010; Pressman, 2011; Sommerville, 2010). In requirement elicitation, the needs of stakeholder and system are collected (Ramdhani, Maylawati, Amin, \& Aulawi, 2018). Then, in analysis and design, we create a system model, among others architecture model and software model using Unified Modelling Language (Booch, 2005, 1998; Maylawati, Darmalaksana, \& Ramdhani, 2018; Maylawati, Ramdhani, \& Amin, 2018). In the implementing and testing phase, we used RapidMiners for analyzing the sentiment of bureaucratic service. Sentiment analysis in RapidMiners uses Deep Learning method is the development of Artificial Neural Network (ANN) method with add multiple hidden layers between input and output layer (Ahmad, Farman, \& Jan, 2019; Schmidhuber, 2015). Moreover, Deep Learning is a popular method with a various algorithm in text analytics research today.

From the explanation above, in this research, qualitative methods are combined with SDLC and Big Data Technology for sentiment analysis from social media. Figure 2 describes about flow activity of research methodology. In requirement, elicitation is implemented a qualitative method with analyzing the phenomena, facts, and condition of bureaucracy in Indonesia. Then, besides collecting the related literature studies, the data from social media are also collected and analyzed that used as an input requirement of sentiment analysis system. Therefore, this is one of the differences with the research before combining information technology techniques and social science.

\section{RESULT AND DISCUSSION}

\section{The Performance of Bureaucrats in the Digital Age}

Bureaucracy is a device/ institution of employees/ HR and a system of government administration carried out by civil servants based on legislation (Damanhuri., 2017). Bureaucracy is a storage place for typical and unique public trust. "In general, the term 'bureaucracy' is regarded as having a negative connotation, although there have been anarchists that enjoyed the excess of formalism and rigor" (Liviora, 2018). There are three bureaucratic concepts, namely (Mariana, 2017) 2) The Concept of Parkinson Law; and 3) Ovulation Concept (2017, p. 93). Bureaucracy is characterized by hierarchy, 


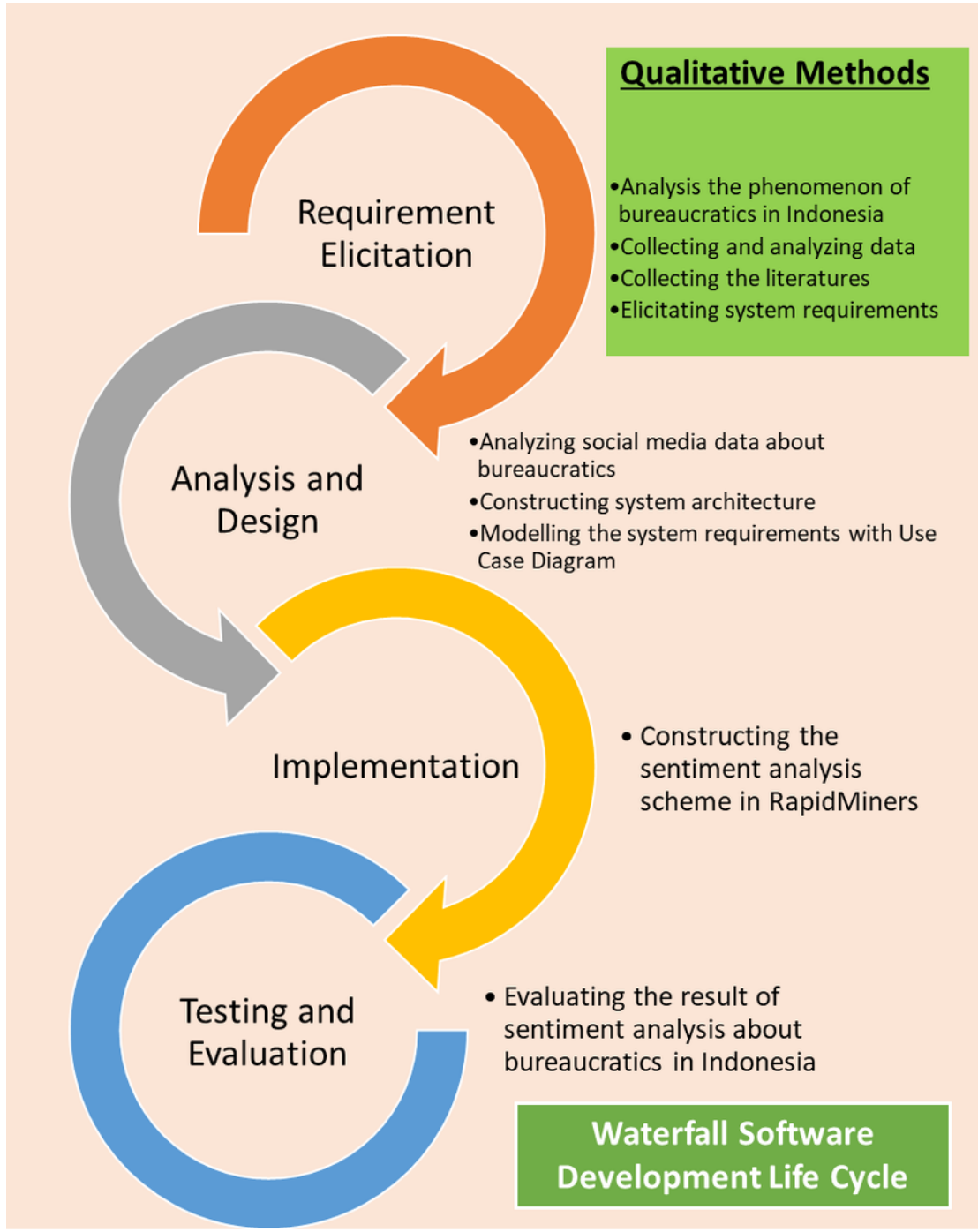

specialization, formalization, and impersonality (Widiyastuti, Andretti Abdillah, \& Kurniawan, 2014). Bureaucracy only emphasizes how the bureaucratic machine should be professionally and rationally run. Furthermore, bureaucracy shows a lot about how government organizations are adopted by means of official kingdoms. The bureaucratic model currently being implemented does not show a system that represents the nature of justice, transparency, and efficiency (Sanrego Nz \& Muhammad, 2013).

Social media is one of the characteristics of technological development in the era of Industry 4.0. In the Industrial 4.0 era, where everything is connected to internet technology (internet of things) (Kemeristekdikti, 2018; Nizam, 2018; Sadiyoko, 2017). Where industry 4.0 is characterized by internet usage in each sector, both in the economy, social, education, and other sectors. The entire process and production utilizes internet technology and utilizes digital technology, artificial intelligence, big data, robotics, etc. which are also known as the disruptive innovation phenomenon (Office of Chief Economist Bank Mandiri, 2018; Sumber Daya: Iptek \& Dikti, 2018). Big data is a very large set of data that can be computationally analyzed to find patterns, trends, associations, and specifically, those 
related to habits and human interactions (Chen \& Zhang, 2014; Sagiroglu \& Sinanc, 2013; Wu, Zhu, $\mathrm{Wu}, \&$ Ding, 2014). In analyzing social media, of course, big data technology is needed, considering that data in the media has big data characteristics. At the beginning of its appearance, big data only has $3 \mathrm{~V}$ characteristics, including volume, variety, and velocity (Sagiroglu \& Sinanc, 2013; Tan, Blake, Saleh, \& Dustdar, 2013). However, there are currently at least $10 \mathrm{~V}, 17 \mathrm{~V}$, up to more, including volume, velocity, variety, veracity, value, validity, variability, venue, vocabulary, vagueness, visualization, etc. (Arockia, Varnekha, \& Veneshia, 2017; Borne, 2014). Social media that has various types of data such as text, images and videos is very suitable if processed with big data technology. Various big data applications are ready to use to process and analyze data from social media to reveal insight knowledge from the data (Panatula, Kumar, \& Geetha, 2019; Vinutha \& Raju, 2018).

The discovery of computer technology is a big leap of human civilization on earth that drives other discoveries, such as digital technology. The digital age is a new paradigm in the government bureaucracy in Indonesia, including the public service sector. This paradigm is an important and radical transition from New Public Management (NPM) towards a digital governance model (Kosorukov, 2017). Most governments in the regions have not been able to implement bureaucratic digitalization because of various factors, including large costs and qualifications of human resources who master technology are still minimal. Although there are exceptions to the cities of Bandung and Banyuwangi which are considered capable of applying modern technology.

Through the use of digital devices (e-government), public services are more efficient, effective, fast, and accurate (Pamoragung, Suryadi, \& Ramdhani, 2006). So that bureaucratic procedures are more practical and brief. Similarly, through digitalization, the number of operational officers can be reduced but the number of services can be increased (Ramdhani, Aulawi, \& Gojali, 2018). Previously, the process of public services such as health services, education, licensing, etc., took a long time/ took a long time. Besides that, direct interaction between bureaucrats or apparatus can encourage acts of corruption and the like.

Rapid technological developments have caused previous technologies to become unused or obsolete, such as hardware or computer software. In addition, it has a direct impact on its users, namely the bureaucrats and apparatus must improve their knowledge and skills with these new devices. If not done it can cause their performance to be unproductive and the level of community satisfaction low. Public services require the involvement of many actors because their implementation is related to many actors. Faulkner also explained the need for cooperation in implementing public services. Government Leadership and Public Services can be generated and sustained a sense of shared purpose and responsibility.

\section{Big Data: A New Paradigm, Challenges, and Constraints}

Big Data can be used by all parties and sectors, including government. For example, for the provision of health services, education, and improving the quality of the bureaucracy and its bureaucrats. The use of big data is important for improving the quality of public services, especially associated with modern developments that require many aspects, including excellent service quality and speed of service processes. At present, the public policy model adopts many services provided by the private sector in order to fulfill public satisfaction as service users. Through big data, policies or programs can be designed appropriately, efficiently and effectively. So far, Big Data has been used by large private companies in improving product quality, developing markets, and choosing the right marketing techniques. Big Data provides accurate data so that programs designed using big data have high accuracy and are economical. Big Data has a variety of data and large so that it is just how to process and use these data for interest.

But Big Data cannot be accessed or processed with traditional devices because of the huge amount of data and many variants. So to access it requires the latest technology. This is an obstacle for some companies and governments in utilizing the potential of Big Data. As is known, most governments are held in a limited and less optimal manner. The limitations of technology-based work devices have 
caused the minimal quality of public services, low bureaucrat work productivity, rigid bureaucratic procedures, and non-optimal results.

This is caused by a variety of factors, including the quality of human resources (HR) and their working devices. Only a few local governments are able to provide the latest technology-based work tools because these facilities are expensive and require professional HR. Knowledge-based works require knowledge of workers. The change in work orientation is a new paradigm and challenges and obstacles for bureaucrats in carrying out efficient and effective bureaucracy. The criteria for efficient and effective bureaucracy is the absolute demand in modern government, namely in order to provide quality and optimal public services.

\section{Sentiment Analysis Architecture as Big Data Technology for Bureaucratic}

The data from social media that is the easiest to process is text. Text is the unstructured data, so that it must be conducted the pre-process until the text data ready to be processed in mining process (Maylawati, Sugilar, \& Yudhiantara, 2018; Maylawati, Ramdhani, Rahman, \& Darmalaksana, 2017; Maylawati \& Saptawati, 2017; Slamet et al., 2018). In the requirement elicitation phase, we defined several requirements of bureaucracy sentiment analyzer application, among others:

1. The application can read the corpus that contains document from social media, such as Twitter, Facebook, or blog and news website;

2. The application can do text pre-processing, such as lowercase, tokenizing, emoticon handling, abbreviation handling, a regular expression (regex) removal, stopwords removal, and stemming;

3. The application can conduct feature extraction, either bag of words or multiple words (n-gram);

4. The application can conduct feature selection, such as removing redundant;

5. The application can do the mining process with a classification technique for sentiment analysis using a specific algorithm, such as the Naive Bayes algorithm, Decision Tree, Artificial Neural Network, and so on. Where in the mining process there are two main processes in classification, among others training process and testing process;

6. The application provides the result of bureaucracy sentiment analysis.

Figure 3 describes the bureaucracy sentiment analyzer architecture, while Figure 4 describes the use case diagram of bureaucracy sentiment analyzer which is representation model of analysis in Waterfall SDLC after requirement elicitation.

Figure 3. Bureaucracy sentiment analyzer architecture

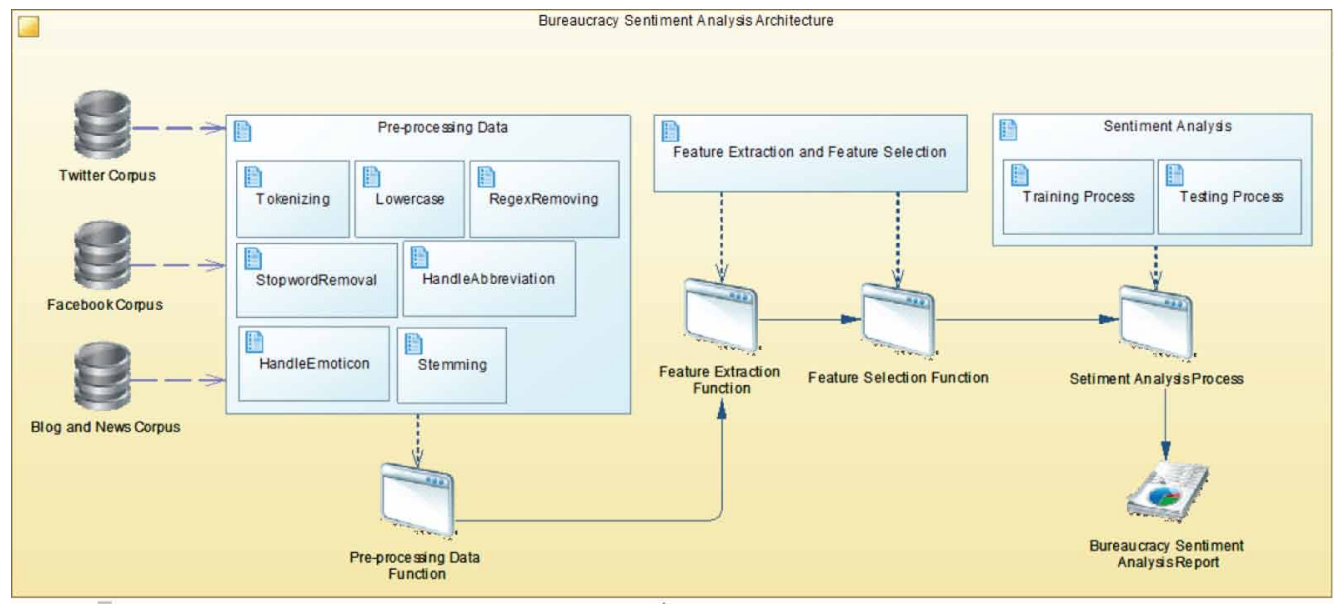




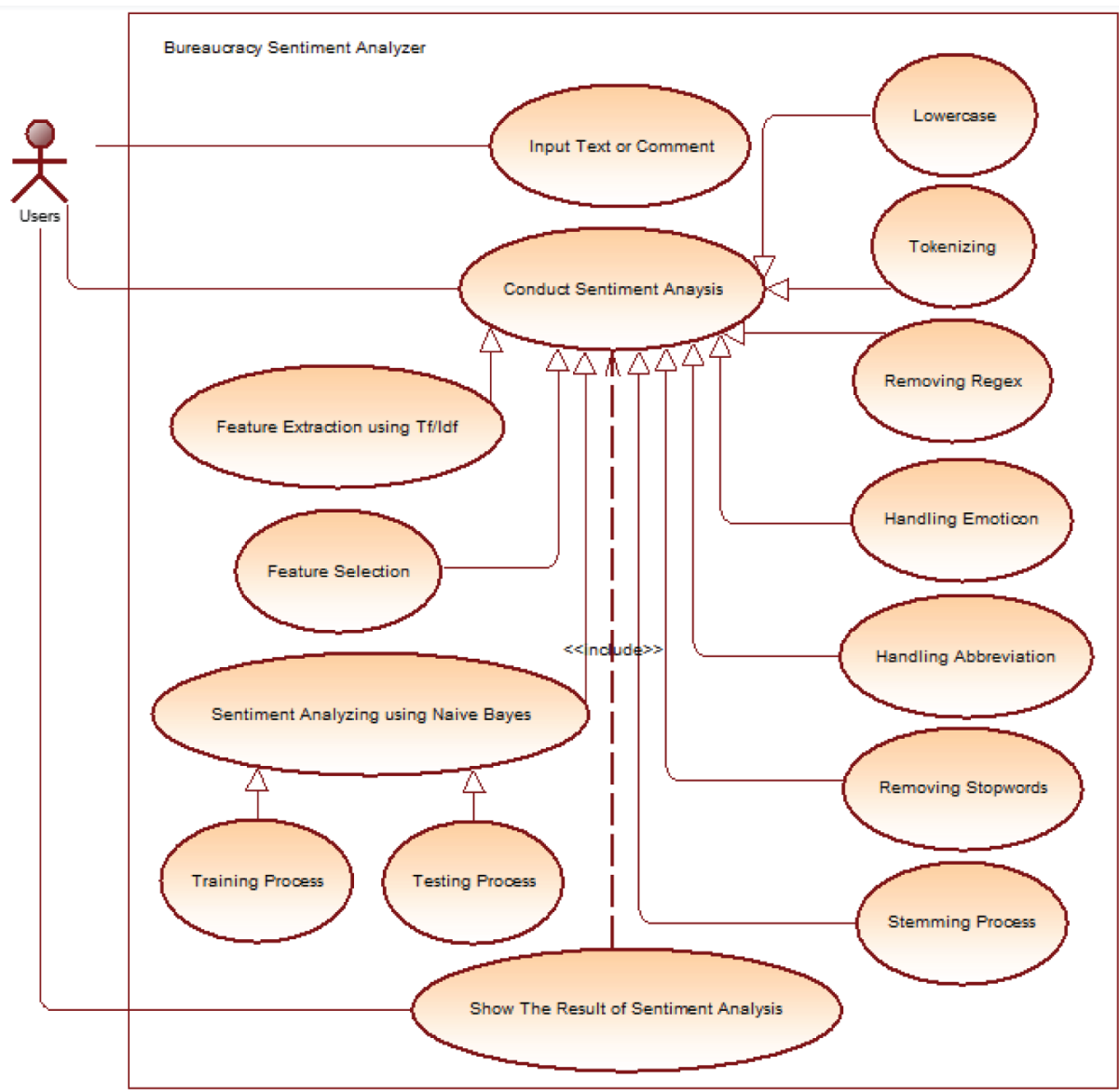

\section{The Example of Sentiment Analysis Application}

Many data mining tools as big data technique that can be used easily, one of which is RapidMiner (Studio, n.d.). This article used RapidMiner as the implementation example for analyzing the sentiment of bureaucrats and bureaucracy service in Indonesia. Figures 5-8 shows the process scheme of bureaucracy sentiment analysis in RapidMiner. In RapidMiner there are many text analytic extensions that can be used easily, among others Aylien (Aylien, n.d.) and Rosette (Rosette, n.d.). All of the text mining or text analytic process has been included in its functions so that we just combine the function in the process and run it. We collect the data from Twitter with the keyword "bureaucracy" and "birokrasi". Sentiment analysis from text data depends on the language. Every language is unique and has different treatment to get clean data and accurate result (Maylawati, 2015; Maylawati, Aulawi, \& Ramdhani, 2019; Maylawati, Zulfikar, Slamet, \& Ramdhani, 2018; Maylawati \& Saptawati, 2017), and RapidMiner is limited to English, German, French, Czech, and Arabic. For another language, RapidMiner provides a general function to insert the dictionary and process it.

Figure 5-8 also describes the result of bureaucracy sentiment analysis from Twitter directly. Figure 5 shows the result of bureaucracy sentiment analysis using Aylien, from 100 tweets from Twitter, 62 tweets have a positive opinion, 32 tweets are negative, and 6 tweets are neutral. While, the result using Rosette quite different (with the same data collection and illustrated in Figure 6), where positive tweets are 21, 40 tweets are negative, and 39 tweets are neutral-. Even though there are different in 
Figure 5. The result of Aylien for bureaucracy sentiment analysis

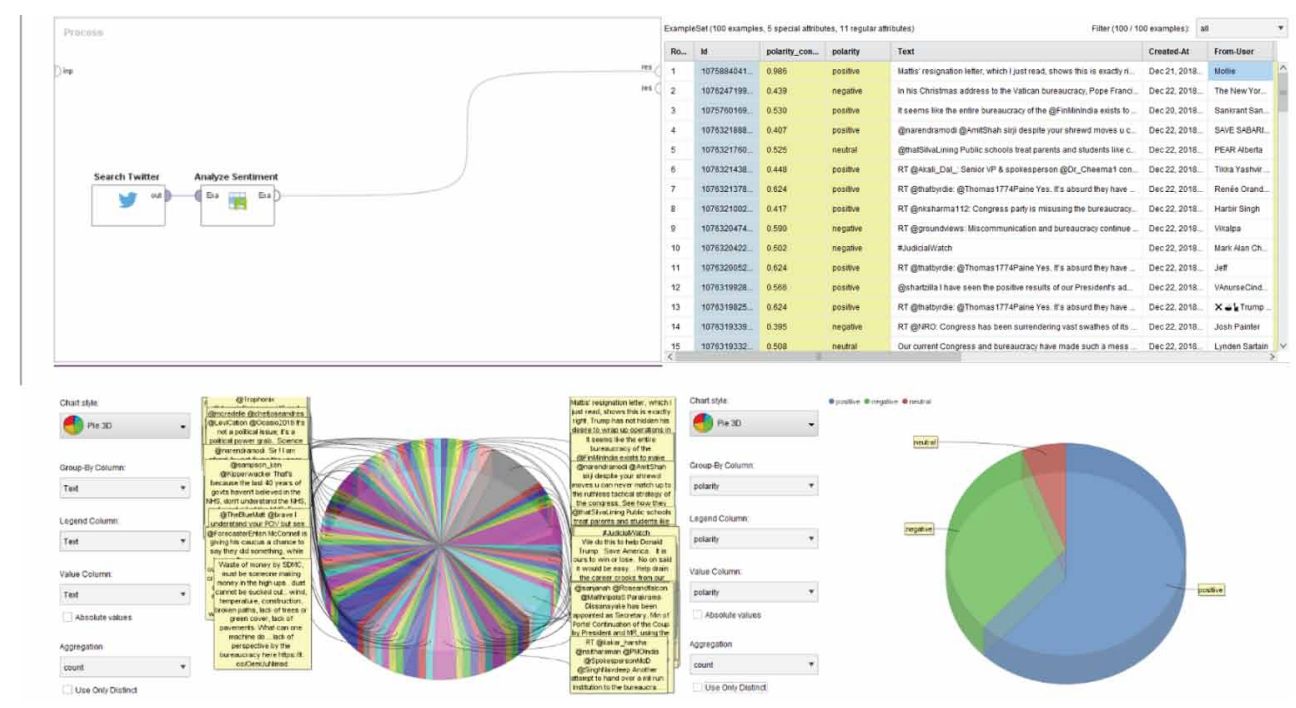

Figure 6. The result of Rosette for bureaucracy sentiment analysis

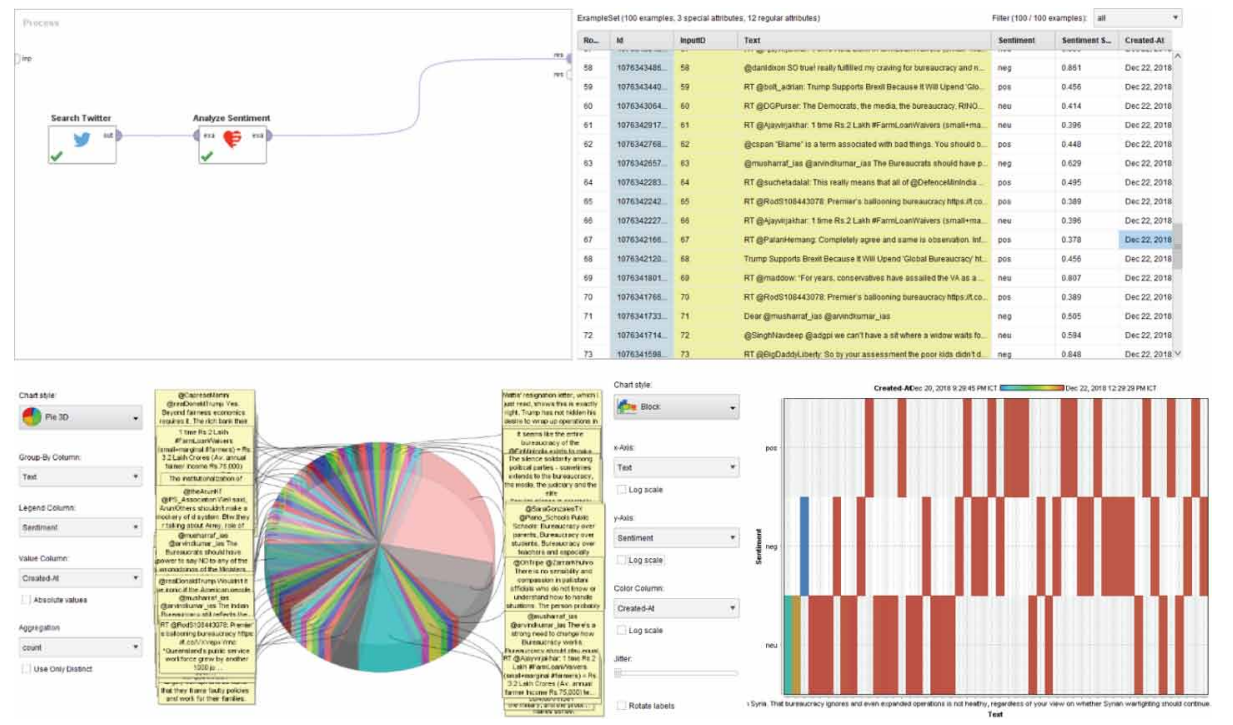

classifying the sentiment, but the important thing is from that experiment (with 100 tweets) around $41.5 \%$ the opinions about bureaucratic service are positive, around 36\% are negative opinion, and around $22.5 \%$ are neutral opinion. It means that the community feels quite satisfied with bureaucratic services, although those who have a positive and neutral opinion are not too much different. However, it remains to be noted that there are also many who think negatively about the existing bureaucratic services. This result can be used as an evaluation material for things that are not suitable, not good so that the community is not satisfied and has a negative opinion on bureaucratic services.

We also collect 200 tweets with the Indonesian language for analyzing the sentiment about bureaucracy in Indonesia. The result of Aylien in Figure 7 shows that only 3 tweets that have a positive 
Figure 7. The result of Aylien for bureaucracy sentiment analysis with Indonesian text

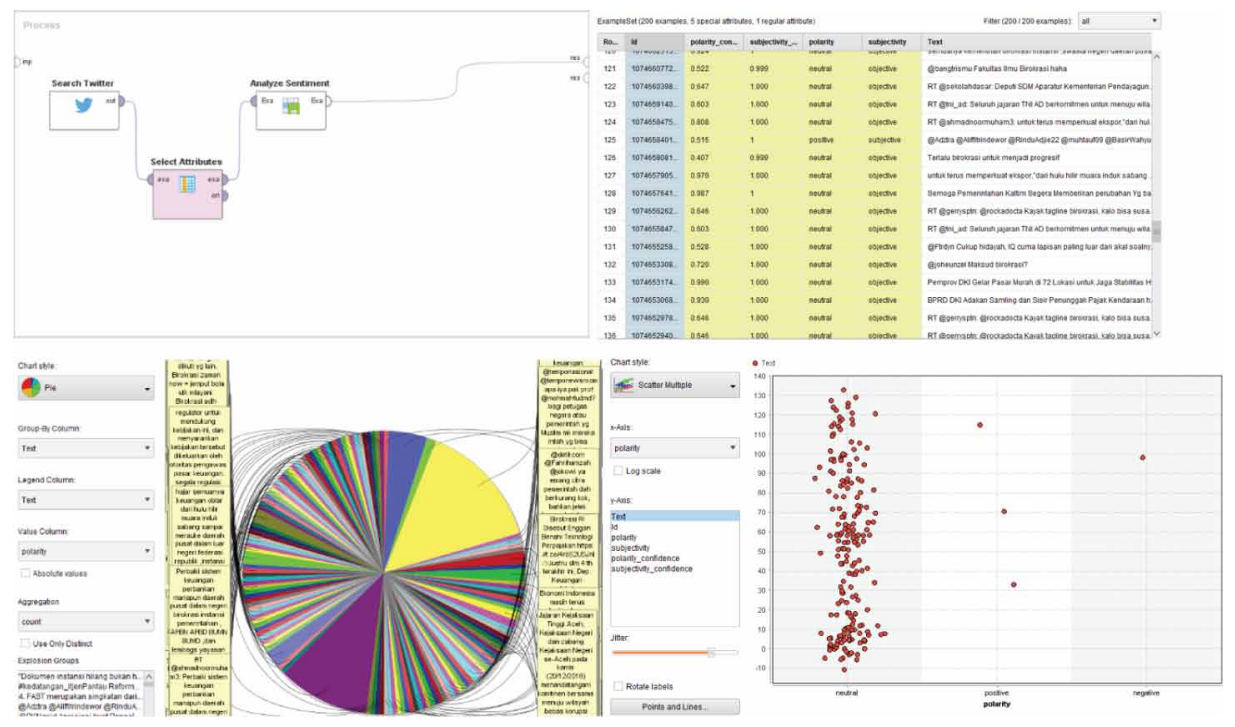

Figure 8. The result of Rosette for bureaucracy sentiment analysis with Indonesian text

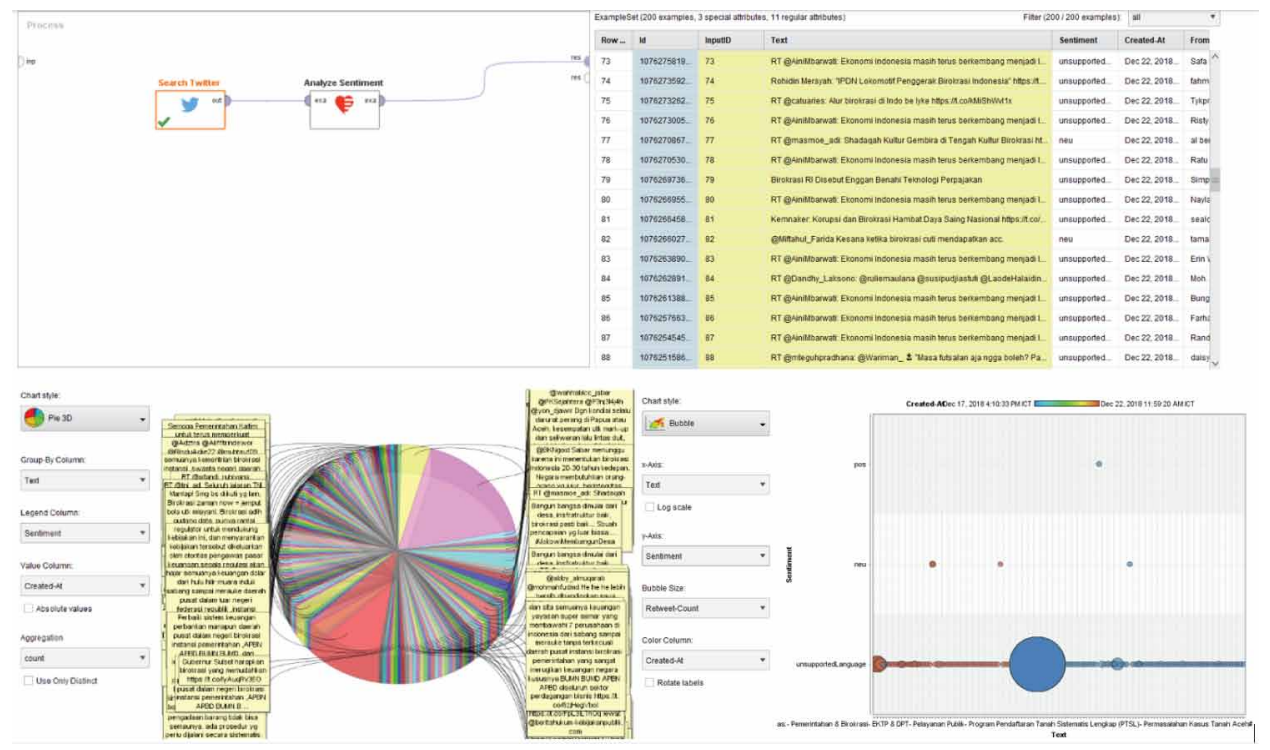

opinion, 1 tweet is negative, and 196 tweets are neutral. While the result using Rosette in Figure 8 shows that 1 tweet is detected has a positive opinion, 0 for the negative tweet, 5 for neutral tweets and 194 tweets for unsupported language. The results of sentiment analysis with Indonesian text in RapidMiner have not been capable yet to be used to analyze the public opinion about bureaucracy in Indonesia, because-it is constrained by language processing that has not been supported by RapidMiner. Those result can be used as an illustration of how the public opinion about bureaucracy. Besides that, the process in RapidMiner is an implementation illustration of sentiment analysis process as big data technique that has been provided in architecture and use case diagram above (in Figure 3 
and 4). The main idea is big data technology can be used to improve bureaucracy service based on society or public opinions.

\section{CONCLUSION}

Bureaucratic reform in most regional governments has not yet materialized. This causes the quality of public services is not optimal and public satisfaction is low. Therefore, the reform process needs to be accelerated. The main obstacle in realizing bureaucracy in accordance with good governance is its human resources, namely bureaucrats. Most bureaucrats are unprofessional, do not have the expertise that is in accordance with the field and work responsibilities. So that the performance of bureaucrats is not optimal. Another obstacle is the factor of working facilities or working devices that are limited and simple. While, the demands of the modern bureaucracy are work devices based on modern technology, such as digital technology. Big data can be utilized by regional government bureaucracies because of the two main factors above, namely bureaucrats and modern technological devices. So that the potential for big data can be used optimally. This article success to design a sentiment analysis architecture and functional model as big data technology for bureaucracy opinion in social media. The experiment proved that the result of sentiment can be used as information to evaluate, to make a decision, and to improve bureaucracy service quality. 


\section{REFERENCES}

Ahmad, J., Farman, H., \& Jan, Z. (2019). Deep Learning Methods and Applications. In Deep Learning: Convergence to Big Data Analytics (pp. 31-42). Springer. doi:10.1007/978-981-13-3459-7_3

Arockia, P. S., Varnekha, S. S., \& Veneshia, K. A. (2017). The 17 V's of Big Data. International Research Journal of Engineering and Technology, 4(9), 3-6. Retrieved from https://irjet.net/archives/V4/i9/IRJET-V4I957.pdf

Aylien. (n.d.). Aylien Text Analytics. Retrieved from https://aylien.com/

Booch, G. (1998). Object-Oriented Analysis and Design (2nd ed.). Santa Clara, CA: Addison-Wesley.

Booch. (2005). The Unified Modeling Language User Guide. Addison-Wesley. Retrieved from http://books. google.com/books?id=xfQ8JCbxDK8C\&pgis=1

Borne, K. (2014). Top 10 List - The V's of Big Data. Data Science Central. Retrieved from https://www. datasciencecentral.com/profiles/blogs/top-10-list-the-v-s-of-big-data

Damanhuri, J. R. (2017). Reaktualisasi reformasi birokrasi menuju good governance. In Prosiding Seminar Nasional Pendidikan FKIP (pp. 297-304).

Haryanto, A. T. (2018). 130 Juta Orang Indonesia Tercatat Aktif di Medsos. Retrieved from https://inet.detik. com/cyberlife/d-3912429/130-juta-orang-indonesia-tercatat-aktif-di-medsos

Hernandez, A. A. (2017). Green IT Adoption Practices in Education Sector : A Developing Country Perspective. International Journal of Sociotechnology and Knowledge Development (IJSKD). doi:10.4018/IJSKD.2017070101

Jumadi, M., D. S. A., Subaeki, B., \& Ridwan, T. (2016). Opinion mining on Twitter microblogging using Support Vector Machine: Public opinion about State Islamic University of Bandung. In Proceedings of 2016 4th International Conference on Cyber and IT Service Management, CITSM 2016. Academic Publisher. doi:10.1109/ CITSM.2016.7577569

Kemeristekdikti. (2018). Pengembangan Iptek dan Pendidikan Tinggi di Era Revolusi Industri 4.0.

Kosorukov, A. A. (2017). Digital government model: Theory and practice of modern public administration. Journal of Legal, Ethical \& Regulatory Issues.

Laksana, N. C. (2018). Ini Jumlah Total Pengguna Media Sosial di Indonesia. Retrieved from https://techno. okezone.com/read/2018/03/13/207/1872093/ini-jumlah-total-pengguna-media-sosial-di-indonesia

Liviora, G., G. (2018). Bureaucratic administration in modern society.

Mariana, D. (2017). Aparatur sipil negara dan reformasi birokrasi. Jurnal Ilmu Politik, 22(1), 91-104.

Maylawati, D. S., Aulawi, H., \& Ramdhani, M. A. (2019). Flexibility of Indonesian text pre-processing library. Indonesian Journal of Electrical Engineering and Computer Science, 13(1), 420-426. doi:10.11591/ijeecs. v13.11.pp420-426

Maylawati, D. S., Darmalaksana, W., \& Ramdhani, M. A. (2018). Systematic Design of Expert System Using Unified Modelling Language. IOP Conference Series. Materials Science and Engineering, 288(1), 012047. doi:10.1088/1757-899X/288/1/012047

Maylawati, D. S., Ramdhani, M. A., \& Amin, A. S. (2018). Tracing the Linkage of Several Unified Modelling Language Diagrams in Software Modelling Based on Best Practices. International Journal of Engineering \& Technology, 7(2.29), 776-780. doi:10.14419/ijet.v7i2.29.14255

Maylawati, D. S., Ramdhani, M. A., Rahman, A., \& Darmalaksana, W. (2017). Incremental technique with set of frequent word item sets for mining large Indonesian text data. In Proceedings of the 2017 5th International Conference on Cyber and IT Service Management CITSM 2017 (pp. 1-6). Academic Publisher. doi:<ALIGNMENT.qj></ALIGNMENT>10.1109/CITSM.2017.8089224

Maylawati, D. S., Sugilar, H., \& Yudhiantara, R. A. (2018). Kualitas perangkat lunak: Modularitas pustaka text pre-processing. Jurnal Perspektif, 1(2). 
Maylawati, D. S., Zulfikar, W. B., Slamet, C., \& Ramdhani, M. A. (2018). An Improved of Stemming Algorithm for Mining Indonesian Text with Slang on Social Media. In Proceedings of the 6th International Conference on Cyber and IT Service Management (CITSM 2018). Academic Publisher. doi:10.1109/CITSM.2018.8674054

Maylawati, D. S. A. (2015). Pembangunan Library pre-processing untuk text mining dengan representasi himpunan frequent word itemset (HFWI) Studi Kasus: Bahasa Gaul Indonesia. Bandung.

Merriam, S. B. (2009). Qualitative Research: A Guide to Design and Implementation. Wiley. doi:10.1017/ CBO9781107415324.004

Moses, J. A. (2015). A project management approach to learning. International Journal of Sociotechnology and Knowledge Development.

Muhammad Nizam, S. (2018). Revolusi industri 4.O: Suatu Pengenalan. Seranta FELDA Jabatan Perdana Menteri.

Nielsen, L. H., \& Storgaard, K., Stage, J., \& Billestrup, J. (2015). A Template for Design Personas: Analysis of 47 Persona Descriptions from Danish Industries and Organizations. International Journal of Sociotechnology and Knowledge Development. doi:10.4018/ijskd.2015010104

Office of Chief Economist Bank Mandiri. (2018). Menghadapi Era RI 4.0.

Pamoragung, A., Suryadi, K., \& Ramdhani, M. A. (2006). Enhancing the Implementation of E-Government in Indonesia through the High-Quality of Virtual Community and Knowledge Portal Design. In Proceedings of the European Conference on e-Government (pp. 341-348).

Panatula, K., G., , Kumar, D., S., , Geetha, T. V. S. K., \& E. , (2019). Performance evaluation of cloud service with hadoop for twitter data. Indonesian Journal of Electrical Engineering and Computer Science, 13(1).

Philip Chen, C. L., \& Zhang, C. Y. (2014). Data-intensive applications, challenges, techniques and technologies: A survey on Big Data. Information Sciences, 275, 314-347. doi:10.1016/j.ins.2014.01.015

Pressman, R. S. (2011). Software Engineering: A Practitioner's Approach (7th ed.). New York: McGraw-Hill.

Ramdhani, M. A., Aulawi, H., \& Gojali, D. (2018). Analysis of determinant factors of e-Government implementation. IOP Conference Series. Materials Science and Engineering, 434, 12049. doi:10.1088/1757$899 \mathrm{X} / 434 / 1 / 012049$

Ramdhani, M. A., Sa'adillah Maylawati, D., Amin, A. S., \& Aulawi, H. (2018). Requirements Elicitation in Software Engineering. IACSIT International Journal of Engineering and Technology. doi:10.14419/ijet. v7i2.29.14254

Rosette. (n.d.). Rosette Text Analytics. Retrieved from https://www.rosette.com/

Ruparelia, N. B. (2010). Software Development Lifecycle Models. Software Engineering Notes, 35(3), 8. doi:10.1145/1764810.1764814

Sa'Adillah Maylawati, D., \& Putri Saptawati, G. A. (2017). Set of Frequent Word Item sets as Feature Representation for Text with Indonesian Slang. In Journal of Physics (Vol. 801). Conference Series; doi:10.1088/1742-6596/801/1/012066

Sa'Adillah Maylawati, D., \& Putri Saptawati, G. A. (2017). Set of Frequent Word Item sets as Feature Representation for Text with Indonesian Slang. Journal of Physics: Conference Series, 801(1). doi:10.1088/17426596/801/1/012066

Sadiyoko, A. (2017). Industry 4.0 Ancaman, Tantangan atau Kesempatan. Oratio Dies XXIV FTI UNPAR.

Sagiroglu, S., \& Sinanc, D. (2013). Big data: A review. In Proceedings of the 2013 International Conference on Collaboration Technologies and Systems, CTS 2013. Academic Press. doi:10.1109/CTS.2013.6567202

Sanrego Nz, Y. D., \& Muhammad, R. (2013). Analisa perbandingan model birokrasi Indonesia: Model modern David Osborne, Ted Gaebler dan pendekatan konsep Islam perspektif Umer Chapra. Jurnal Al-Muzara'ah, $1(1), 18-38$.

Schmidhuber, J. (2015). Deep Learning in neural networks: An overview. Neural Networks, 61, 85-117. doi:10.1016/j.neunet.2014.09.003 PMID:25462637 
Slamet, C., Atmadja, A. R., Maylawati, D. S., Lestari, R. S., Darmalaksana, W., \& Ramdhani, M. A. (2018). Automated Text Summarization for Indonesian Article Using Vector Space Model. In Proceedings of the IOP Conference Series: Materials Science and Engineering. doi:10.1088/1757-899X/288/1/012037

Sommerville, I. (2010). Software Engineering. In Software Engineering. doi:10.1111/j.1365-2362.2005.01463.x Rapidminer Studio. (n.d.). RapidMiner. Retrieved from https://rapidminer.com/

Sumber Daya: Iptek \& Dikti. (2018). Era Revolusi Industri 4.0 Saatnya Generasi Millenial Menjadi Dosen Masa Depan.

Tan, W., Blake, M. B., Saleh, I., \& Dustdar, S. (2013). Social-network-sourced big data analytics. IEEE Internet Computing, 17(5), 62-69. doi:10.1109/MIC.2013.100

Tavallaei, M., \& Talib, M. A. (2010). A general perspective on role of theory in qualitative research. Journal of International Social Research, 3(11).

Tracy, J. S. (2016). Qualitative Research Methods. United Kingdom: Wiley-Blackwell.

Vinutha, D. \& Raju, G.T. (18AD). An Accurate and Efficient Scheduler for Hadoop MapReduce Framework. Indonesian Journal of Electrical Engineering and Computer Science 2, 12(3).

Widiyastuti, S., Abdillah, L.A., \& Kurniawan. (2014). Sistem Informasi Eksekutif Bagian Kepegawaian Pada Pt. Pelindo Ii (Persero) Palembang. Seminar Nasional Teknologi Informasi, Komunikasi Dan Manajemen.

Wu, X., Zhu, X., Wu, G. Q., \& Ding, W. (2014). Data mining with big data. IEEE Transactions on Knowledge and Data Engineering. doi:10.1109/TKDE.2013.109

Yeo, A. W., Zaman, T., \& Kulathuramaiyer, N. (2013). Indigenous Knowledge Management in the Kelabit Community in Eastern Malaysia: Insights and Reflections for Contemporary KM Design. International Journal of Sociotechnology and Knowledge Development, 5(1), 23-36. doi:10.4018/jskd.2013010103 


\title{
Call for Articles
}

\section{International Journal of Sociotechnology and Knowledge Development}

\author{
Volume $11 \cdot$ Issue 3 • July-September 2019 • ISSN: 1941-6253 • eISSN: 1941-6261 \\ An official publication of the Information Resources Management Association
}

\section{MISSION}

The overall mission of the International Journal of Sociotechnology and Knowledge Development (IJSKD) is to provide a practical and comprehensive forum for exchanging research ideas and down-to-earth practices which bridge the social and technical gap within organizations and society at large. At the same time it will provide a forum for considering the ethical issues linked to organizational change and development. It will encourage interdisciplinary texts that discuss current practices as well as demonstrating how the advances of and changes within - technology affect the growth of society (and vice versa). The aim of the journal is to bring together the expertise of people who have worked practically in a changing society across the world for people in the field of organizational development and technology studies including information systems development and implementation.

\section{COVERAGE AND MAJOR TOPICS}

The topics of interest in this journal include, but are not limited to:

Applied ergonomic - Computer-supported cooperative work • Critical success factors (and key performance indicators) for organizations and technological implementation $\bullet$ Culture and trust within organizations and their relevance to technological artifacts - Design and technology development issues including requirements and stakeholder participation $\bullet$ E-government and democracy as affected by technological change $\bullet$ Empowerment and team development $\bullet$ HRM issues for innovation and knowledge sharing $\bullet$ Human-Computer Interaction • Humanistic redesign and technological politics in organizations $\bullet$ Implementation issues of change and technology - Influence of human factors on operational efficiency $\bullet$ Information systems development $\bullet$ Innovation $\bullet$ Internet studies $\bullet$ Knowledge communication $\bullet$ Knowledge management systems $\bullet$ Knowledge Sharing $\bullet$ Learning Organizations $\bullet$ Managing organizational knowledge as a strategic asset $\bullet$ Organizational Change $\bullet$ Performance and quality of working life • Quality assessment of computer information systems • Relevance of the worker's perspective $\bullet$ Social aspects of automation $\bullet$ Sociotechnical Systems $\bullet$ Systems failures $\bullet$ Technological forecasting and social change $\bullet$ Technology and its role in society and organizations • Technology in society $\bullet$ Using knowledge management principles to solve organizational performance problems

ALL INQUIRIES REGARDING IJSKD SHOULD BE DIRECTED TO THE ATTENTION OF:

Lincoln Christopher Wood, Editor-in-Chief•IJSKD@igi-global.com

ALL MANUSCRIPT SUBMISSIONS TO IJSKD SHOULD BE SENT THROUGH THE ONLINE SUBMISSION SYSTEM: http://www.igi-global.com/authorseditors/titlesubmission/newproject.aspx

IDEAS FOR SPECIAL THEME ISSUES MAY BE SUBMITTED TO THE EDITOR(S)-IN-CHIEF

\section{PLEASE RECOMMEND THIS PUBLICATION TO YOUR LIBRARIAN}

For a convenient easy-to-use library recommendation form, please visit:

http://www.igi-global.com/IJSKD 


\title{
Call for Articles
}

\section{International Journal of Sociotechnology and Knowledge Development}

\author{
Volume $11 \cdot$ Issue 3 • July-September 2019 • ISSN: 1941-6253 • eISSN: 1941-6261 \\ An official publication of the Information Resources Management Association
}

\section{MISSION}

The overall mission of the International Journal of Sociotechnology and Knowledge Development (IJSKD) is to provide a practical and comprehensive forum for exchanging research ideas and down-to-earth practices which bridge the social and technical gap within organizations and society at large. At the same time it will provide a forum for considering the ethical issues linked to organizational change and development. It will encourage interdisciplinary texts that discuss current practices as well as demonstrating how the advances of and changes within - technology affect the growth of society (and vice versa). The aim of the journal is to bring together the expertise of people who have worked practically in a changing society across the world for people in the field of organizational development and technology studies including information systems development and implementation.

\section{COVERAGE AND MAJOR TOPICS}

The topics of interest in this journal include, but are not limited to:

Applied ergonomic - Computer-supported cooperative work • Critical success factors (and key performance indicators) for organizations and technological implementation $\bullet$ Culture and trust within organizations and their relevance to technological artifacts - Design and technology development issues including requirements and stakeholder participation $\bullet$ E-government and democracy as affected by technological change $\bullet$ Empowerment and team development $\bullet$ HRM issues for innovation and knowledge sharing $\bullet$ Human-Computer Interaction • Humanistic redesign and technological politics in organizations $\bullet$ Implementation issues of change and technology - Influence of human factors on operational efficiency $\bullet$ Information systems development $\bullet$ Innovation $\bullet$ Internet studies $\bullet$ Knowledge communication $\bullet$ Knowledge management systems $\bullet$ Knowledge Sharing $\bullet$ Learning Organizations $\bullet$ Managing organizational knowledge as a strategic asset $\bullet$ Organizational Change $\bullet$ Performance and quality of working life • Quality assessment of computer information systems • Relevance of the worker's perspective $\bullet$ Social aspects of automation $\bullet$ Sociotechnical Systems $\bullet$ Systems failures $\bullet$ Technological forecasting and social change $\bullet$ Technology and its role in society and organizations • Technology in society $\bullet$ Using knowledge management principles to solve organizational performance problems

ALL INQUIRIES REGARDING IJSKD SHOULD BE DIRECTED TO THE ATTENTION OF:

Lincoln Christopher Wood, Editor-in-Chief•IJSKD@igi-global.com

ALL MANUSCRIPT SUBMISSIONS TO IJSKD SHOULD BE SENT THROUGH THE ONLINE SUBMISSION SYSTEM: http://www.igi-global.com/authorseditors/titlesubmission/newproject.aspx

IDEAS FOR SPECIAL THEME ISSUES MAY BE SUBMITTED TO THE EDITOR(S)-IN-CHIEF

\section{PLEASE RECOMMEND THIS PUBLICATION TO YOUR LIBRARIAN}

For a convenient easy-to-use library recommendation form, please visit:

http://www.igi-global.com/IJSKD 
This contract, for the manuscript The Concept of Big Data in Bureaucratic Service using Sentiment Analysis, submitted to the journal International Journal of Sociotechnology and Knowledge Development (IJSKD), was agreed to by Dian Sa'adillah Maylawati on May 11, 2019 at 11:36 PM.

Upon execution of this contract by all parties, it becomes a legally binding contract. Therefore, please read this contract carefully before agreeing.

We are pleased that you have selected an IGI Global publication for submitting your contribution. For the sake of efficiency and effectiveness of the publication process, please complete and submit this form so that your submission can be immediately entered into the peer review process. If your submission is not accepted for publication or is withdrawn prior to the final acceptance being issued, the agreement is considered void and the copyright for the contribution is returned to you. The consideration of your submission for publication cannot proceed until a signed copy of this agreement is submitted.

The author(s) hereby warrants that the manuscript named above that has been submitted to IGI Global for publication in the named book or any other IGI Global publication, IS ORIGINAL AND HAS NOT BEEN SUBMITTED FOR PUBLICATION OR PUBLISHED ELSEWHERE, and that all trademark use within the manuscript has been credited to its owner or written permission to use the name has been granted. In addition, the author(s) acknowledges that all images such as tables, screenshots, graphics, etc., do not have a copyright that is held by a third party. IGI Global will not accept a manuscript for which the copyright is held by a third party. Authors may not use substantial verbatim text from another copyrighted work without the written permission of the copyright holder.

The author(s) in consideration of the publication of the above named manuscript also understands:

1. Author(s) agrees to, and does hereby assign all rights, title and interest, including copyrights, in and to the manuscript to Publisher. The author retains the rights to any intellectual property developed by the author and included in the manuscript including, without limitation, any models, theories, or conclusions formulated by the author. While the author may use any and all thoughts and research results developed or accumulated while working on a manuscript, and may rewrite, update, and re-title them for use in other publications, the author CANNOT use the verbatim text of the manuscript or any part thereof that has been copyrighted by IGI Global without first obtaining the written permission of IGI Global.

When the manuscript is ready for publication, it will be published at Publisher's own expense, under the Publisher's imprint or any other imprint the Publisher in its sole discretion elects.

2. When a manuscript is accepted for publication, author(s) understand that when submitting the final version of their accepted submission:

- The file is submitted in Word format.

- The text has been professionally copyedited and is considered final and ready for publication without any further text changes.

- The references and citations follow strict APA style. 
3. Author(s) understand that no royalties or remuneration will be paid by the Publisher to the author for the above named submitted manuscript. Further, Author(s) acknowledge the manuscript is being provided on a volunteer basis for the professional recognition obtained by the publication.

4. The Author(s) will indemnify and defend Publisher against any claim, demand or recovery against Publisher by reason of any violation of any proprietary right or copyright, or because of any libelous or scandalous matter contained in the Manuscript. Publisher has the unrestricted right to withdraw a publication either pre- or post-publication that is found to include plagiarism or copyright infringement.

5. IGI Global supports a Fair Use Policy where under this policy you may utilize your final typeset PDF (which includes the title page, table of contents and other front materials, and the copyright statement) of your chapter or article of this publication (NOT the entire book or journal issue), in your teaching materials or post to your own secure personal website and/or university repository site. Under the Fair Use Policy, however, authors and editors ARE NOT authorized to upload their chapter, article, or full book publication or journal issue to open access sites, including, but not limited to: ResearchGate, Academia.edu, SSRN, arXiv, or any others. Doing so is considered a clear violation of the International Copyright Laws and violators could face legal consequences.

6. The Publisher will have the right to edit the work for the original edition and for any revision, provided that the meaning of the text is not materially altered. Publisher is solely responsible for the right to make all decisions on page layout and all other aspects of preparing the publication as they relate to suitability to the publisher's system, procedures, and business practices.

7. The Publisher will provide each Author with an electronic PDF file of the Author's typeset manuscript as proof of publication.

8. When the Publisher decides that the public demand for this work no longer warrants its continued manufacture, the Publisher may discontinue manufacture and destroy any or all plates, books, and sheets without liability to the Author.

9. The Publisher may permit others to publish, broadcast, make recordings or mechanical renditions, publish book club and micro-film editions, make translations, and other electronic versions, quote, and otherwise utilize this work and material based on this work provided the author's name accompanies the work.

10. This Agreement, whenever called upon to be construed, shall be governed by the laws of the Commonwealth of Pennsylvania.

11. The parties to this Agreement consent and agree that all legal proceedings relating to the subject matter of this Agreement shall be maintained in the Court of Common Pleas of Dauphin County, Pennsylvania, or, if applicable, the United States District Court for the 
Middle District of Pennsylvania, and all parties hereto consent and agree that jurisdiction and venue for such proceedings shall lie exclusively within said Courts.

12. This Agreement represents the entire understanding between the parties hereto with respect to the subject matter hereof and this Agreement supersedes all previous representations, understandings of agreements, oral or written, between the parties with respect to subject matter hereof and cannot be modified except by a written instrument signed by the parties hereto.

13. This Agreement shall be binding upon the parties hereto, their heirs, successors, assigns and personal representatives.

IMPORTANT NOTE: This agreement must be submitted with your completed manuscript before IGI Global will agree to publish your manuscript. IGI Global will not publish any manuscript that is not accompanied by an accepted agreement. Please note that this is a legally binding contract.

As the corresponding author of this paper, I am signing on my behalf, as well as the behalf of the co-authors of this paper (if applicable) with their authorization and acceptance, to the terms and conditions of this binding Publication Agreement.

( ${ }^{*}$ If for any reason you are not authorized to sign on behalf of the co-authors of this paper, please emaildevelopment@igi-global.com with inquiries) 
This contract, for the manuscript The Concept of Big Data in Bureaucratic Service using Sentiment Analysis, submitted to the journal International Journal of Sociotechnology and Knowledge Development (IJSKD), was agreed to by Dian Sa'adillah Maylawati on May 11, 2019 at 11:36 PM.

Upon execution of this contract by all parties, it becomes a legally binding contract. Therefore, please read this contract carefully before agreeing.

We are pleased that you have selected an IGI Global publication for submitting your contribution. For the sake of efficiency and effectiveness of the publication process, please complete and submit this form so that your submission can be immediately entered into the peer review process. If your submission is not accepted for publication or is withdrawn prior to the final acceptance being issued, the agreement is considered void and the copyright for the contribution is returned to you. The consideration of your submission for publication cannot proceed until a signed copy of this agreement is submitted.

The author(s) hereby warrants that the manuscript named above that has been submitted to IGI Global for publication in the named book or any other IGI Global publication, IS ORIGINAL AND HAS NOT BEEN SUBMITTED FOR PUBLICATION OR PUBLISHED ELSEWHERE, and that all trademark use within the manuscript has been credited to its owner or written permission to use the name has been granted. In addition, the author(s) acknowledges that all images such as tables, screenshots, graphics, etc., do not have a copyright that is held by a third party. IGI Global will not accept a manuscript for which the copyright is held by a third party. Authors may not use substantial verbatim text from another copyrighted work without the written permission of the copyright holder.

The author(s) in consideration of the publication of the above named manuscript also understands:

1. Author(s) agrees to, and does hereby assign all rights, title and interest, including copyrights, in and to the manuscript to Publisher. The author retains the rights to any intellectual property developed by the author and included in the manuscript including, without limitation, any models, theories, or conclusions formulated by the author. While the author may use any and all thoughts and research results developed or accumulated while working on a manuscript, and may rewrite, update, and re-title them for use in other publications, the author CANNOT use the verbatim text of the manuscript or any part thereof that has been copyrighted by IGI Global without first obtaining the written permission of IGI Global.

When the manuscript is ready for publication, it will be published at Publisher's own expense, under the Publisher's imprint or any other imprint the Publisher in its sole discretion elects.

2. When a manuscript is accepted for publication, author(s) understand that when submitting the final version of their accepted submission:

- The file is submitted in Word format.

- The text has been professionally copyedited and is considered final and ready for publication without any further text changes.

- The references and citations follow strict APA style. 
3. Author(s) understand that no royalties or remuneration will be paid by the Publisher to the author for the above named submitted manuscript. Further, Author(s) acknowledge the manuscript is being provided on a volunteer basis for the professional recognition obtained by the publication.

4. The Author(s) will indemnify and defend Publisher against any claim, demand or recovery against Publisher by reason of any violation of any proprietary right or copyright, or because of any libelous or scandalous matter contained in the Manuscript. Publisher has the unrestricted right to withdraw a publication either pre- or post-publication that is found to include plagiarism or copyright infringement.

5. IGI Global supports a Fair Use Policy where under this policy you may utilize your final typeset PDF (which includes the title page, table of contents and other front materials, and the copyright statement) of your chapter or article of this publication (NOT the entire book or journal issue), in your teaching materials or post to your own secure personal website and/or university repository site. Under the Fair Use Policy, however, authors and editors ARE NOT authorized to upload their chapter, article, or full book publication or journal issue to open access sites, including, but not limited to: ResearchGate, Academia.edu, SSRN, arXiv, or any others. Doing so is considered a clear violation of the International Copyright Laws and violators could face legal consequences.

6. The Publisher will have the right to edit the work for the original edition and for any revision, provided that the meaning of the text is not materially altered. Publisher is solely responsible for the right to make all decisions on page layout and all other aspects of preparing the publication as they relate to suitability to the publisher's system, procedures, and business practices.

7. The Publisher will provide each Author with an electronic PDF file of the Author's typeset manuscript as proof of publication.

8. When the Publisher decides that the public demand for this work no longer warrants its continued manufacture, the Publisher may discontinue manufacture and destroy any or all plates, books, and sheets without liability to the Author.

9. The Publisher may permit others to publish, broadcast, make recordings or mechanical renditions, publish book club and micro-film editions, make translations, and other electronic versions, quote, and otherwise utilize this work and material based on this work provided the author's name accompanies the work.

10. This Agreement, whenever called upon to be construed, shall be governed by the laws of the Commonwealth of Pennsylvania.

11. The parties to this Agreement consent and agree that all legal proceedings relating to the subject matter of this Agreement shall be maintained in the Court of Common Pleas of Dauphin County, Pennsylvania, or, if applicable, the United States District Court for the 
Middle District of Pennsylvania, and all parties hereto consent and agree that jurisdiction and venue for such proceedings shall lie exclusively within said Courts.

12. This Agreement represents the entire understanding between the parties hereto with respect to the subject matter hereof and this Agreement supersedes all previous representations, understandings of agreements, oral or written, between the parties with respect to subject matter hereof and cannot be modified except by a written instrument signed by the parties hereto.

13. This Agreement shall be binding upon the parties hereto, their heirs, successors, assigns and personal representatives.

IMPORTANT NOTE: This agreement must be submitted with your completed manuscript before IGI Global will agree to publish your manuscript. IGI Global will not publish any manuscript that is not accompanied by an accepted agreement. Please note that this is a legally binding contract.

As the corresponding author of this paper, I am signing on my behalf, as well as the behalf of the co-authors of this paper (if applicable) with their authorization and acceptance, to the terms and conditions of this binding Publication Agreement.

( ${ }^{*}$ If for any reason you are not authorized to sign on behalf of the co-authors of this paper, please emaildevelopment@igi-global.com with inquiries) 


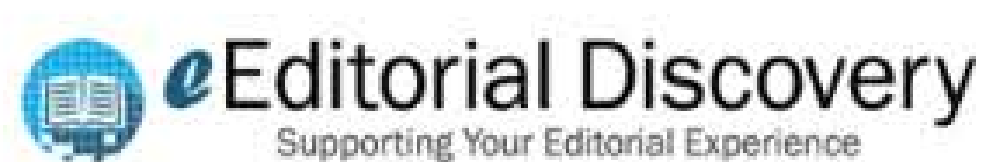

IGIGlobal

User Guides - $\quad$ Author \& Editor Resources

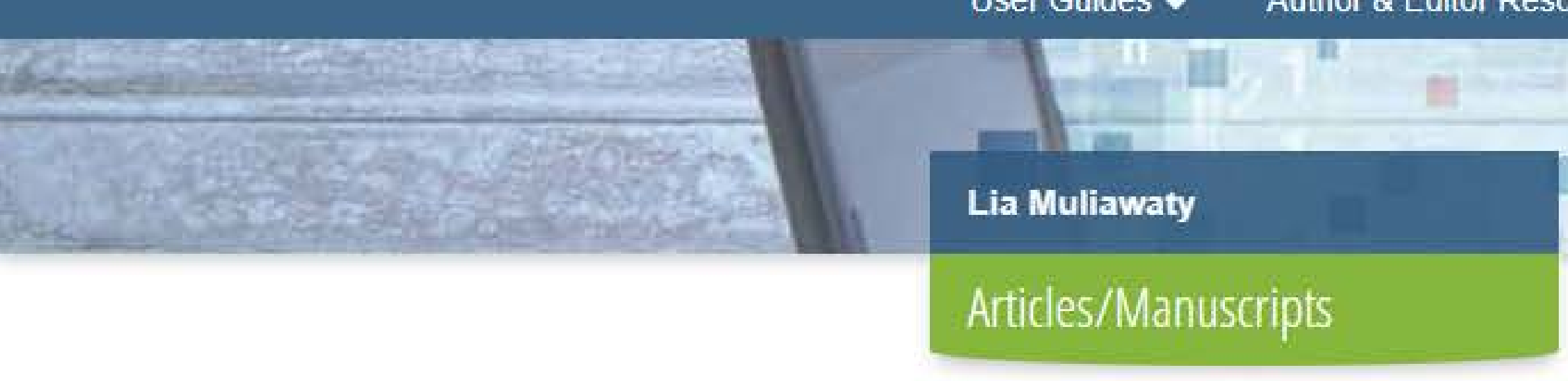

Selectideselect all | Total results: 1

IJSKD: Volume 11, Issue 3, Article 1.

The Concept of Big Data in Bureaucratic Service using Sentiment Analysis (180319-115516)

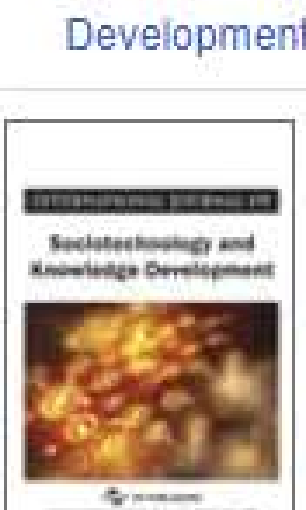
Discoverability

Complimentary Copy

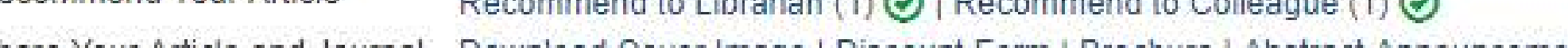

Promotional Opportunities

Submitted Forms

Questions?

Submit Your Conferences \& Events $(0)$ 金

View All Submitted Forms (2

Contact marketing@igi-global.com

Resources

2 Editors-in-Chief

$\mathbf{2}$ Corresp. Author

2 Authors

Brian Galli (brian galli@liu.edu), Lincoln Wood (Lincoln Wood@otago ac nz)

Dian Maylawati (dsaadillah@sttgarut ac.id)

Lia Muliawaty (lia.muliawaty@unpas.ac.id), Kamal Alamsyah (apih.amay007@gmail.com), Ummu Salamah
Sort by: Submitted (desc) -

Phase History
Date Started-Date Completed

, Published

- Download Final Materials

, Revision Received
$5 / 252019-5 / 30 / 2019$

1 Editor-in-Chief Revision

Requested

LEARN MOR

- Books I System User Guide - Journals I Contact Us

Publishing Inquiries

RESOURCES

Submission Guidelines | Fair Use Policy | Abstracting \& Indexing

neEditorial Discovery
山) Call-For-Articles.pdf
山l Masthead.pdf

^山 The-Concept-of-Bi...pdf ^

山10.4018@USKD.20...pdf 、

D. ijskd.png

ㄴ] $10.1 .1 .658 .5511 . \mathrm{pd}$
Show all

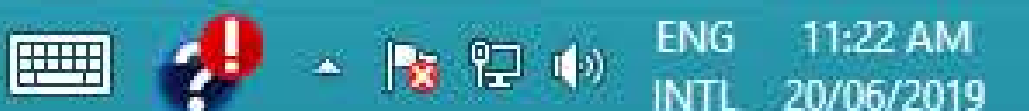




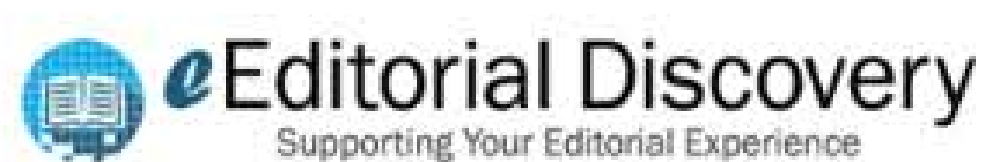

IGIGlobal

User Guides - $\quad$ Author \& Editor Resources

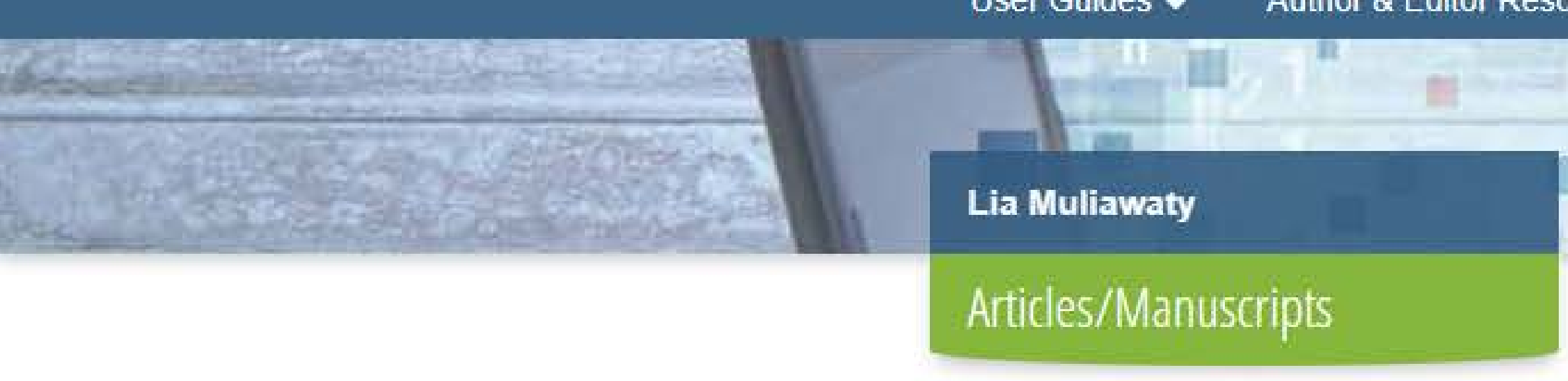

Selectideselect all | Total results: 1

IJSKD: Volume 11, Issue 3, Article 1.

The Concept of Big Data in Bureaucratic Service using Sentiment Analysis (180319-115516)

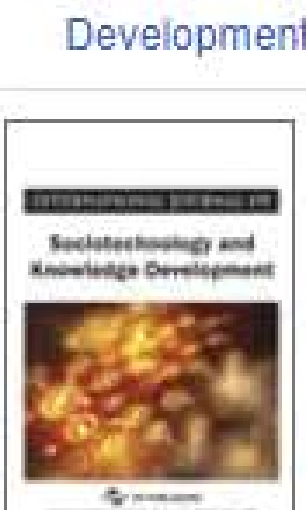
Discoverability

Complimentary Copy

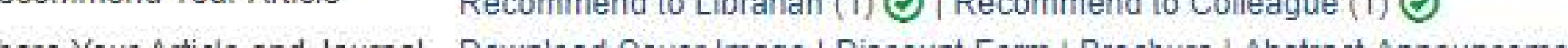

Promotional Opportunities

Submitted Forms

Questions?

Submit Your Conferences \& Events $(0)$ 金

View All Submitted Forms (2

Contact marketing@igi-global.com

Resources

2 Editors-in-Chief

$\mathbf{2}$ Corresp. Author

2 Authors

Brian Galli (brian galli@liu.edu), Lincoln Wood (Lincoln Wood@otago ac nz)

Dian Maylawati (dsaadillah@sttgarut ac.id)

Lia Muliawaty (lia.muliawaty@unpas.ac.id), Kamal Alamsyah (apih.amay007@gmail.com), Ummu Salamah
Sort by: Submitted (desc) -

Phase History
Date Started-Date Completed

, Published

- Download Final Materials

, Revision Received
$5 / 252019-5 / 30 / 2019$

1 Editor-in-Chief Revision

Requested

LEARN MOR

- Books I System User Guide - Journals I Contact Us

Publishing Inquiries

RESOURCES

Submission Guidelines | Fair Use Policy | Abstracting \& Indexing

neEditorial Discovery
山) Call-For-Articles.pdf
山l Masthead.pdf

^山 The-Concept-of-Bi...pdf ^

山10.4018@USKD.20...pdf 、

D. ijskd.png

ㄴ] $10.1 .1 .658 .5511 . \mathrm{pd}$
Show all

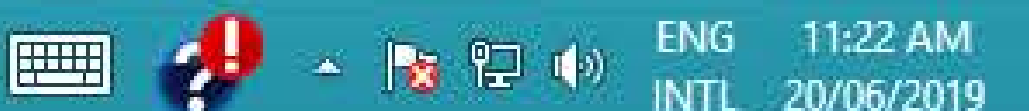


(7. Manuscript Info. ๑2. Authors $\odot$ 3. Documents $\odot$ 4. Figures $\odot 5$. Overvien

Manuscript Title

The Concept of Big Data in Bureaucratic Service using Sentiment Analysis

Manuscript Subtitle (optional)

Character count 0

Keywords

Comma separated I.st of 8-15 keywords that figure prominentiv in your manuscript. These words should primarily include important vocabulary, names of people, and names of organizations. We will use these terms to generate the index for the journal issue. Please do not include words that are part of the journal title or manuscript title Maximum length-200 characters Must be tite case. Must be comma separated

Big Data, Bureaucrats, Bureaucratic Reform, Digital, New Public Service, Opinion Mining, Sentiment Analysis, Social Media, Text Mining

\section{Abstract}

Your abstract should provide readers with an overview of the content of your manuscript It is important that your abstract clearly states the purpose of your manuscript and summarizes

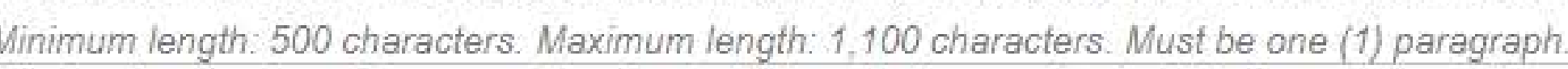

The implementation of bureaucratic reform in Indonesia is not optimal which faces various obstacles. At present public services demand excellent service and meet public satisfaction -The obstacles are rigid bureaucracy, incompetent bureaucrats or apparatuses, not professional, and technological gaps. Rapid technological development, such as digital technology and big data, has not been responded positively by most bureaucrats. Big data is a great potential for improving bureaucratic and public services. With qualitative method and Waterfall Software Development Life Cycle, this article provides the design of bureaucracy sentiment analysis application as implementation of big data technology for analyzing the opinion abou showed that sentiment analysis as big data technique for bureaucracy service based on society opinion can be used to evaluate bueaucratic service performance better.

Total Number of Authors Credited on Title Page

Manuscript Type

Research Article

Journal

International Journal of Sociotechnology and Knowledge Development (IJSKD) 
(7. Manuscript Info. ๑2. Authors $\odot$ 3. Documents $\odot$ 4. Figures $\odot 5$. Overvien

Manuscript Title

The Concept of Big Data in Bureaucratic Service using Sentiment Analysis

Manuscript Subtitle (optional)

Character count 0

Keywords

Comma separated I.st of 8-15 keywords that figure prominentiv in your manuscript. These words should primarily include important vocabulary, names of people, and names of organizations. We will use these terms to generate the index for the journal issue. Please do not include words that are part of the journal title or manuscript title Maximum length-200 characters Must be tite case. Must be comma separated

Big Data, Bureaucrats, Bureaucratic Reform, Digital, New Public Service, Opinion Mining, Sentiment Analysis, Social Media, Text Mining

\section{Abstract}

Your abstract should provide readers with an overview of the content of your manuscript It is important that your abstract clearly states the purpose of your manuscript and summarizes

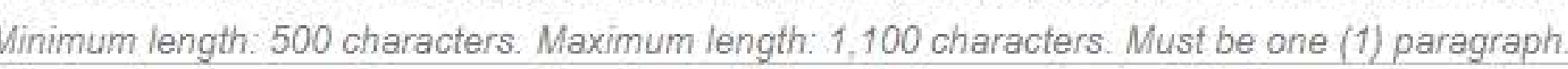

The implementation of bureaucratic reform in Indonesia is not optimal which faces various obstacles. At present public services demand excellent service and meet public satisfaction -The obstacles are rigid bureaucracy, incompetent bureaucrats or apparatuses, not professional, and technological gaps. Rapid technological development, such as digital technology and big data, has not been responded positively by most bureaucrats. Big data is a great potential for improving bureaucratic and public services. With qualitative method and Waterfall Software Development Life Cycle, this article provides the design of bureaucracy sentiment analysis application as implementation of big data technology for analyzing the opinion abou showed that sentiment analysis as big data technique for bureaucracy service based on society opinion can be used to evaluate bueaucratic service performance better.

Total Number of Authors Credited on Title Page

Manuscript Type

Research Article

Journal

International Journal of Sociotechnology and Knowledge Development (IJSKD) 


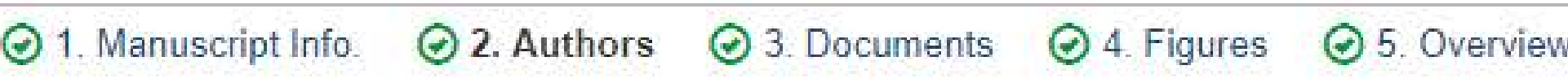

Locked

This paper has been published and new resource additions are no longer being accepted. To request an exception, please contact us:

For book chapters: booksubmissionsystemadmin@igi-global.com
For journal manuscripts: journalsubmissionsystemadmin@igi-global.com

Current Resources

Show Complete Details o

Author 1

Dr. Lia Muliawaty, Universitas Pasundan (lia.muliawaty@unpas.ac.id) 


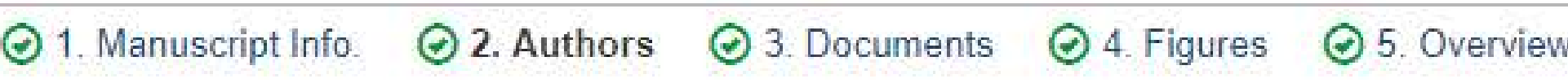

Locked

This paper has been published and new resource additions are no longer being accepted. To request an exception, please contact us:

For book chapters: booksubmissionsystemadmin@igi-global.com
For journal manuscripts: journalsubmissionsystemadmin@igi-global.com

Current Resources

Show Complete Details o

Author 1

Dr. Lia Muliawaty, Universitas Pasundan (lia.muliawaty@unpas.ac.id) 


\section{Manuscriptichapter}

IRevisedwithTrackChangel LISKD BigDatafor Bureaucratics.docx Priman

Show Previous Revisions

Upiloaded by: Dian Ss'aciliah Maylawat (May 25, 201912 12:23 AM)

(A Aperox Word Count 4025

Tale page: Not res

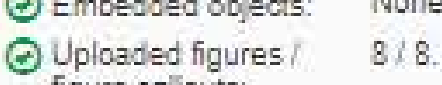

Aigure cascuts:

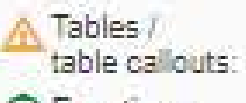

4/0. Each table must have a corresponding callout

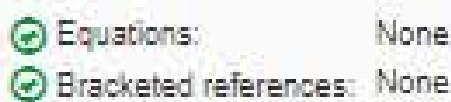

Other

IJSKD Response to Reviewerd docx Primary

Remove $C$ EST

\section{Reviewer Comments for Author}

Reviewer \#2.docx Primary

Remove Elit

Reviewer \#1.docx Primary

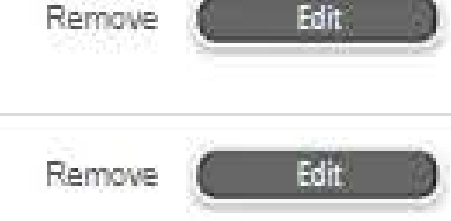

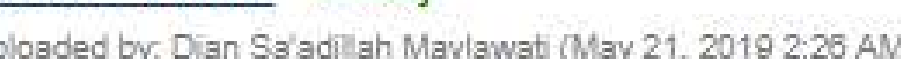

Copyright Agreement

IJSKD Copyright Agreement docx Primary

Uploaded by: Dian Ssiadiah Maylawat (May 15. 2019 1:23 AM

WSKD Copyright Agreement.docx Primary

Remove

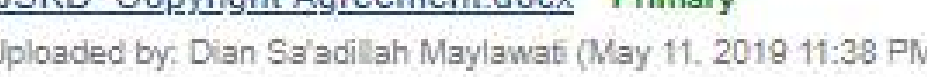

Remove

Revision Notes

IJSKD Revision Note.docx

Renowe

Manuscriptichapter - Identifying Information Removed

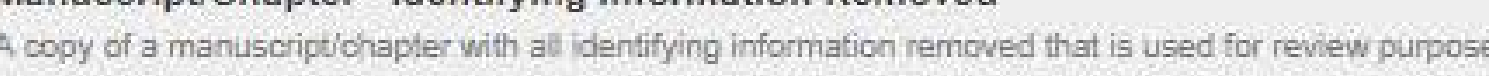

Reviewer copy.docx Primary
Uploaded by. Jaimie Watts (Mar 18, 2019 11:56 AM)

Remove 


\section{Manuscriptichapter}

IRevisedwithTrackChangel LISKD BigDatafor Bureaucratics.docx Priman

Show Previous Revisions

Upiloaded by: Dian Ss'aciliah Maylawat (May 25, 201912 12:23 AM)

(A Aperox Word Count 4025

Tale page: Not res

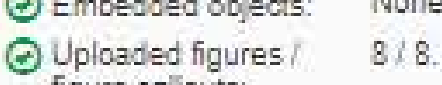

Aigure cascuts:

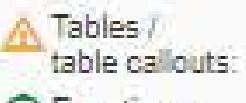

4/0. Each table must have a corresponding callout

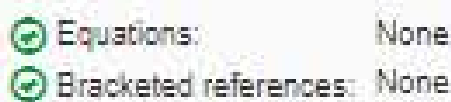

Other

IJSKD Response to Reviewerd docx Primary

Remove $C$ EST

\section{Reviewer Comments for Author}

Reviewer \#2.docx Primary

Remove Elit

Reviewer \#1.docx Primary

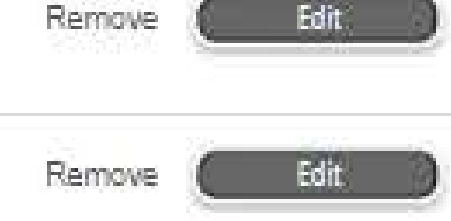

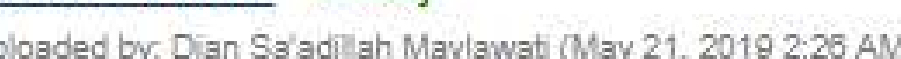

Copyright Agreement

IJSKD Copyright Agreement docx Primary

Uploaded by: Dian Ssiadiah Maylawat (May 15. 2019 1:23 AM

WSKD Copyright Agreement.docx Primary

Remove

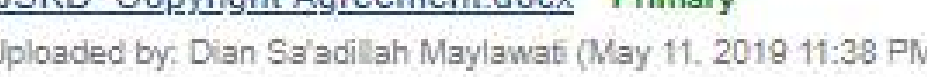

Remove

Revision Notes

IJSKD Revision Note.docx

Renowe

Manuscriptichapter - Identifying Information Removed

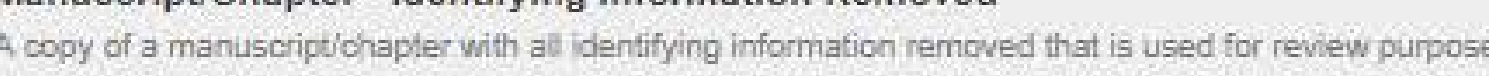

Reviewer copy.docx Primary
Uploaded by. Jaimie Watts (Mar 18, 2019 11:56 AM)

Remove 
Uploaded by: Dian Sa'adillah Maylawati (May 25, 2019 12:23 AM)

(-) Approx. Word Count: 4625.

Title page: Not removed. Tittle, authors/affiliations, abstract, and keywords must be removed from your document.
OEmbedded objects: None-

OUploaded figures: $8 / 8$

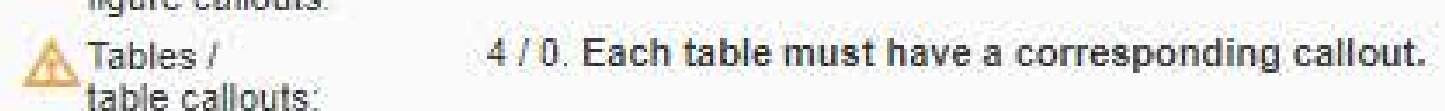

(1) Equations: None. Please review your document to ensure this is correct

Bracketed references: None

Revised_Reviewer1_Reviewer2_IJSKD_BigDataforBureaucratics.docx

Uploaded by: Dian Sa'adillah Maylawati (May 21, 2019 2:25 AM)

(1) Approx. Word Count: 4455.

Title page: Not removed. Title, authors/affiliations, abstract, and keywords must be removed from your document

๑) Uploaded figures: 1 ( $8 / 8$

Uploaded fifures
figure callouts

Aables I

4/0. Each table must have a corresponding callout.

(- Equations:

None. Please review your document to ensure this is correct.

[RevisedwithTrackChange]_IJSKD_ResponseToReviewer_ReviewerCopy_Big__atafor_Bureaucratics.docx

uploaded by: Dian Sa'adillah Maylawati (May 11, 2019 11:00 PM)

(1) Approx. Word Count: 4455

Title page: Not removed. Title, authors/affiliations, abstract, and keywords must be removed from your documen-

(2) Embedded objects: Non

- (-) Uploaded figures/
figure callouts:

$\triangle \triangle_{\text {tables }}^{\text {Tallouts: }}$

OEquations:

10. Each table must have a corresponding callout.

O) Bracketeded references: None

IJSKD_BigDataforBureaucratics.docx

Uploaded by: Dian Sa'adillah Maylawati (Jan 6, 2019 3:39 AM)

(-) Approx. Word Count: 4201

A Title page:

(-) Embedded objects: None.

Uploaded figures / 8/7. Each uploaded figure must have a corresponding callout in the Word document. Upload figures now

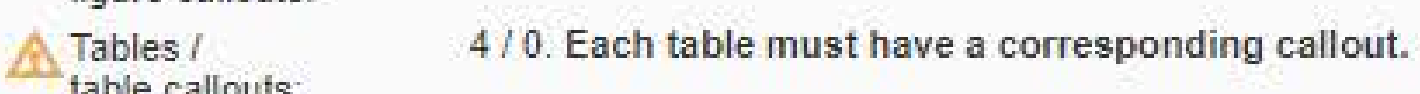

table callous

(2) Equations: None. P 
Uploaded by: Dian Sa'adillah Maylawati (May 25, 2019 12:23 AM)

(-) Approx. Word Count: 4625.

Title page: Not removed. Tittle, authors/affiliations, abstract, and keywords must be removed from your document.
OEmbedded objects: None-

OUploaded figures: $8 / 8$

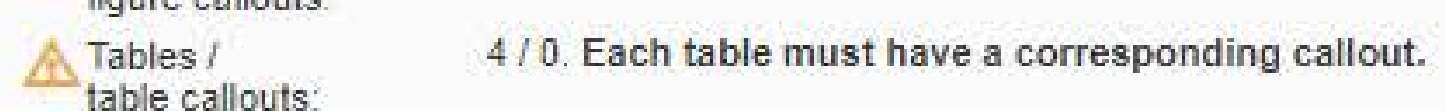

(1) Equations: None. Please review your document to ensure this is correct

Bracketed references: None

Revised_Reviewer1_Reviewer2_IJSKD_BigDataforBureaucratics.docx

Uploaded by: Dian Sa'adillah Maylawati (May 21, 2019 2:25 AM)

(1) Approx. Word Count: 4455.

Title page: Not removed. Title, authors/affiliations, abstract, and keywords must be removed from your document

๑) Uploaded figures: 1 ( $8 / 8$

Uploaded fifures
figure callouts

Aables I

4/0. Each table must have a corresponding callout.

(- Equations:

None. Please review your document to ensure this is correct.

[RevisedwithTrackChange]_IJSKD_ResponseToReviewer_ReviewerCopy_Big__atafor_Bureaucratics.docx

uploaded by: Dian Sa'adillah Maylawati (May 11, 2019 11:00 PM)

(1) Approx. Word Count: 4455

Title page: Not removed. Title, authors/affiliations, abstract, and keywords must be removed from your documen-

(2) Embedded objects: Non

- (-) Uploaded figures/
figure callouts:

$\triangle \triangle_{\text {tables }}^{\text {Tallouts: }}$

OEquations:

10. Each table must have a corresponding callout.

O) Bracketeded references: None

IJSKD_BigDataforBureaucratics.docx

Uploaded by: Dian Sa'adillah Maylawati (Jan 6, 2019 3:39 AM)

(-) Approx. Word Count: 4201

A Title page:

(-) Embedded objects: None.

Uploaded figures / 8/7. Each uploaded figure must have a corresponding callout in the Word document. Upload figures now

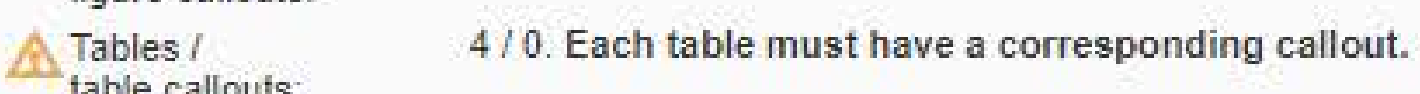

table callous

(2) Equations: None. P 
Other

ISSKD_Response to Reviewerdocx Primary

Reviewer \#2.docx Primary

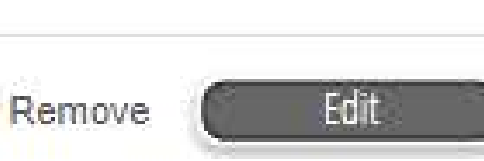

Reviewer \#1.docx Primary

Remove Edit

Uploaded by: Dian Sa'adillah Maylawati (May 21, 2019 2:26 AM)

\section{Revision Notes}


Other

ISSKD_Response to Reviewerdocx Primary

Reviewer \#2.docx Primary

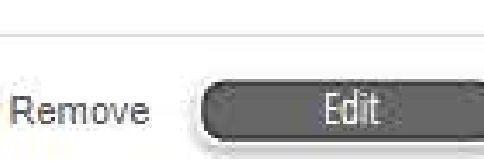

Reviewer \#1.docx Primary

Remove Edit

Uploaded by: Dian Sa'adillah Maylawati (May 21, 2019 2:26 AM)

\section{Revision Notes}




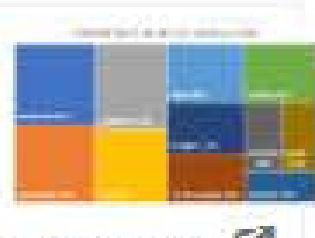

Figure 1
Figure+1.tif

Dimensions: $6.49^{n} \times 3.9^{n}$

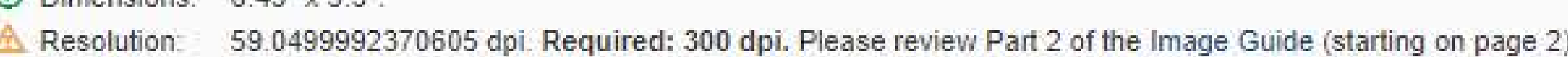

Figure 2

Eigure+2.tif

$\mathrm{E}=$

nt Prevew

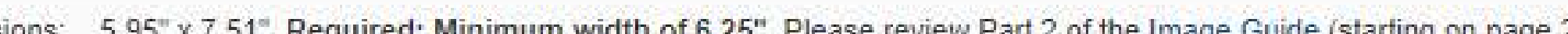

A Resolution: 149.966999511719 dpi. Required: 300 dpi. Please review Part 2 of the Image Guide (starting on page 2 ).

Figure 3

Figure 3

Print Preview U U Uploaded by: Dian Sa'adillah Maylawati (May 11, 2019 11:02 PM)

(9) Dimensions: $6.5^{\circ} \times 2.93^{n}$

Resolution 96.0120010375977 dpi. Required: 300 dpi. Please review Part 2 of the Image Guide (starting on page 2 )

\section{Figure 4}

Figure+4.tif

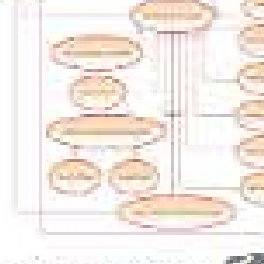

uploaded by: Dian Sa'adillah Maylawati (May 11, 2019 11:02 PN

Print Preview

Dimensions: $6.51 " x 6.17$

$\triangle$ Resolution: 37.7900009155273 dpi. Required: 300 dpi. Please review Part 2 of the Image Guide (starting on page 2 .

- 1 Figure 5

Print Prevew CE Uploaded by: Dian Sa'adillah Maylawati (May 11, 2019 11:02 PM 


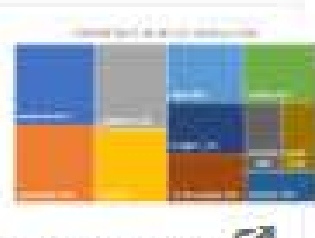

Figure 1
Figure+1.tif

Dimensions: $6.49^{n} \times 3.9^{n}$

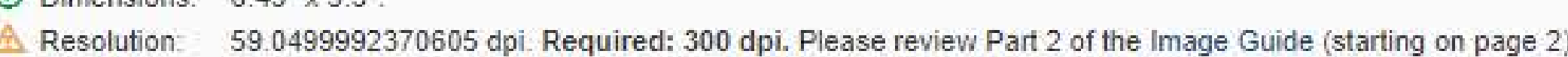

Figure 2

Eigure+2.tif

$\mathrm{E}=$

nt Prevew

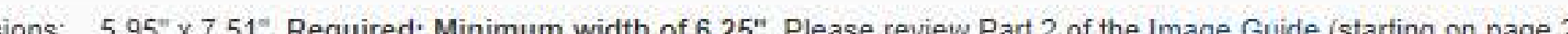

A Resolution: 149.966999511719 dpi. Required: 300 dpi. Please review Part 2 of the Image Guide (starting on page 2 ).

Figure 3

Figure 3

Print Preview U U Uploaded by: Dian Sa'adillah Maylawati (May 11, 2019 11:02 PM)

(9) Dimensions: $6.5^{\circ} \times 2.93^{n}$

Resolution 96.0120010375977 dpi. Required: 300 dpi. Please review Part 2 of the Image Guide (starting on page 2 )

\section{Figure 4}

Figure+4.tif

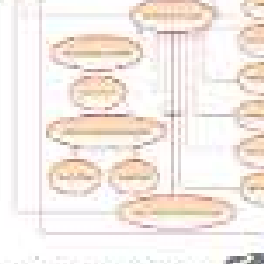

uploaded by: Dian Sa'adillah Maylawati (May 11, 2019 11:02 PN

Print Preview

Dimensions: $6.51 " x 6.17$

$\triangle$ Resolution: 37.7900009155273 dpi. Required: 300 dpi. Please review Part 2 of the Image Guide (starting on page 2 .

- 1 Figure 5

Print Prevew CE Uploaded by: Dian Sa'adillah Maylawati (May 11, 2019 11:02 PM 


\section{The Concept of Big Data in Bureaucratic Service using Sentiment} Analysis

Lia Muliawaty
Universitas Pasundan
Kamal Alamsyah
Universitas Pasundan
Ummu Salamah
Universitas Pasundan
Dian Sa'adillah Maylawati
Uin Sunan Gunung Djati Bandung, Universiti Teknikal Malaysia Melaka

\section{ABSTRACT}

The mplementation of bureaucratic reform in Indonesia is not optimal which faces various obstacles. At present public services demand excellent service and meet public

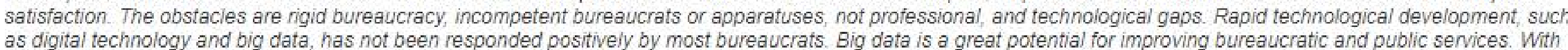
qualititive method and Wateriall Soffuare Devel looment Life Cycle, this article provides the design of bureaucracy sentiment analysis apolication as implementation of big data technology for analyzing the opinion about bureaucracy service in indonesia. So that, the quality of bureaucrats and bureaucracy services can be increased based on society
opinion. The result of experiment using RapidMiner showed that sentiment analysis as big data technique for bureaucracy service based on society opinion can be used to opinion. The result of experimentusing napiatter bueaucratic service performance better.

Keywords: Big Data, Bureaucrats, Bureaucratic Reform, Digital, New Public Service, Opinion Mining, Sentiment Analysis, Social Media, Text Mining

Title

The Concept of Big Data in Bureaucratic Service using Sentiment Analysis

Abstract

The implementation of bureaucratic reform in Indonesia is not optimal which faces various obstacles. At present public services demand excellent service and meet public as digital technology and big data, has not been responded positively by most bureaucrats. Big data is a great potential for improving bureauccratic and public services. With

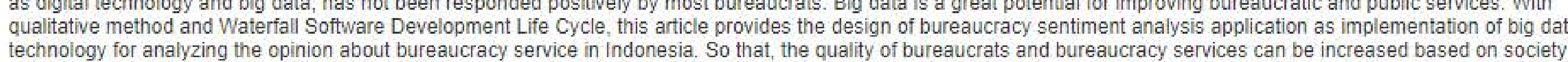
opinion. The result of experiment using Rapidiminer showed that sentiment analysis as big data technique for bureaucracy service based on socieity opinion can be used to
ovaluate 


\section{The Concept of Big Data in Bureaucratic Service using Sentiment} Analysis

Lia Muliawaty
Universitas Pasundan
Kamal Alamsyah
Universitas Pasundan
Ummu Salamah
Universitas Pasundan
Dian Sa'adillah Maylawati
Uin Sunan Gunung Djati Bandung, Universiti Teknikal Malaysia Melaka

\section{ABSTRACT}

The mplementation of bureaucratic reform in Indonesia is not optimal which faces various obstacles. At present public services demand excellent service and meet public

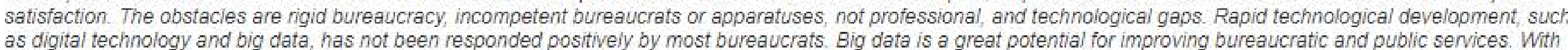
qualititive method and Wateriall Soffuare Devel looment Life Cycle, this article provides the design of bureaucracy sentiment analysis apolication as implementation of big data technology for analyzing the opinion about bureaucracy service in indonesia. So that, the quality of bureaucrats and bureaucracy services can be increased based on society
opinion. The result of experiment using RapidMiner showed that sentiment analysis as big data technique for bureaucracy service based on society opinion can be used to opinion. The result of experimentusing napiatter bueaucratic service performance better.

Keywords: Big Data, Bureaucrats, Bureaucratic Reform, Digital, New Public Service, Opinion Mining, Sentiment Analysis, Social Media, Text Mining

Title

The Concept of Big Data in Bureaucratic Service using Sentiment Analysis

Abstract

The implementation of bureaucratic reform in Indonesia is not optimal which faces various obstacles. At present public services demand excellent service and meet public as digital technology and big data, has not been responded positively by most bureaucrats. Big data is a great potential for improving bureauccratic and public services. With

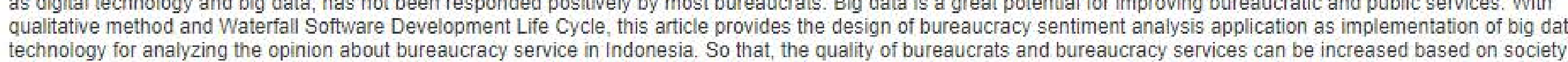
opinion. The result of experiment using Rapidiminer showed that sentiment analysis as big data technique for bureaucracy service based on socieity opinion can be used to
ovaluate 


\section{International Journal of Sociotechnology and Knowledge}

Development

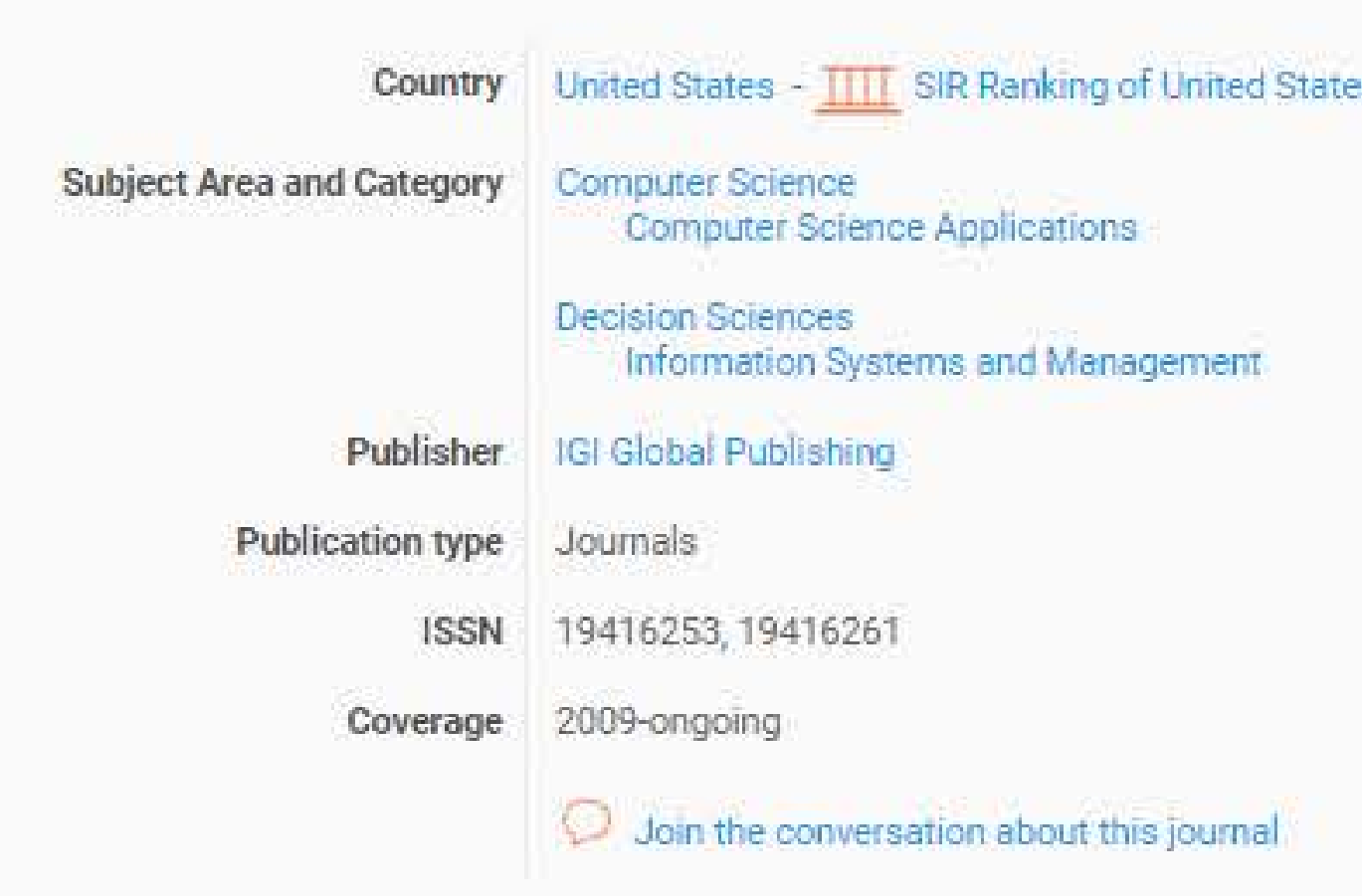

Quartiles

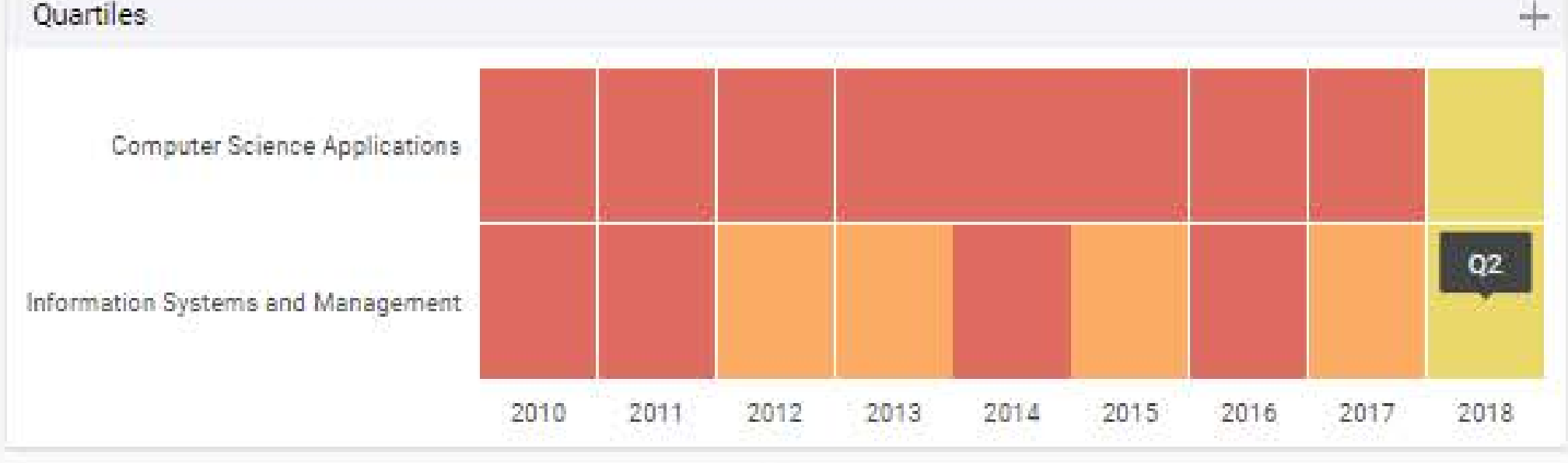

- Total Cites - Self-Cites

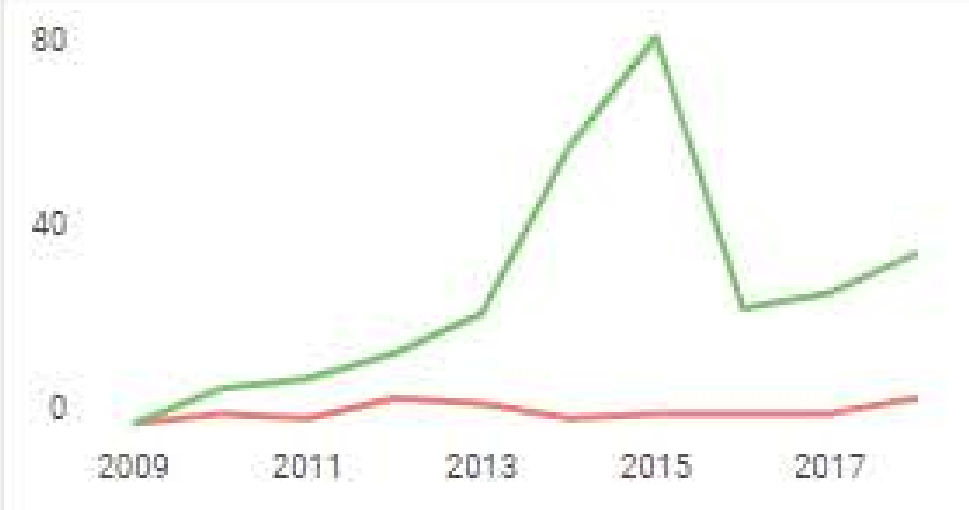

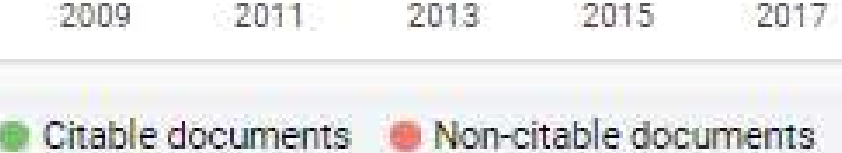

50

so
- External Cires per Doc $\bullet$ Cites per Doc
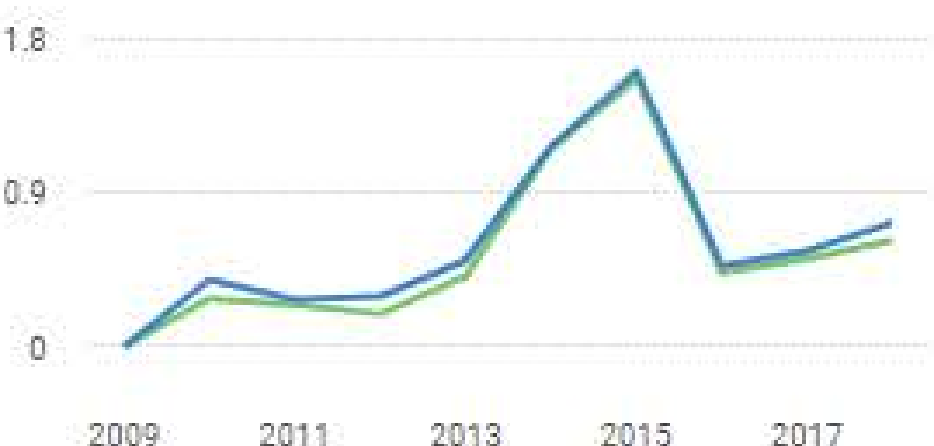

$2009 \quad 2011 \quad 2013 \quad 2015 \quad 2017$

Cited documents - Uncited documents

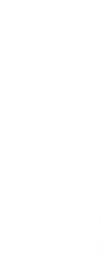

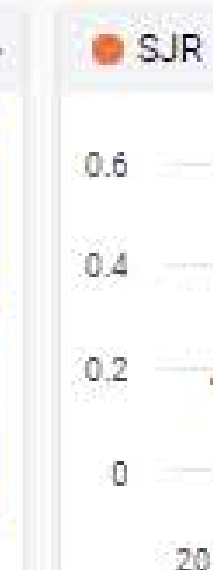

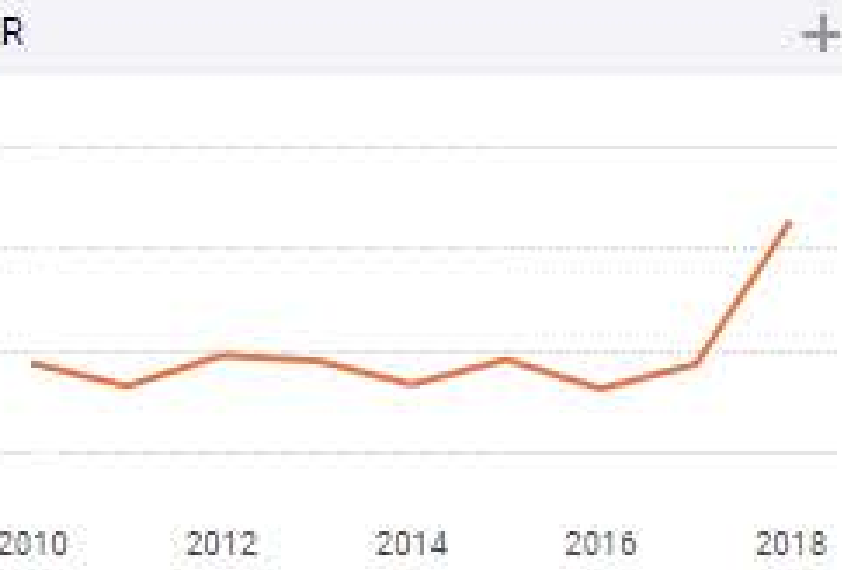

- \% intermational collaboration

40

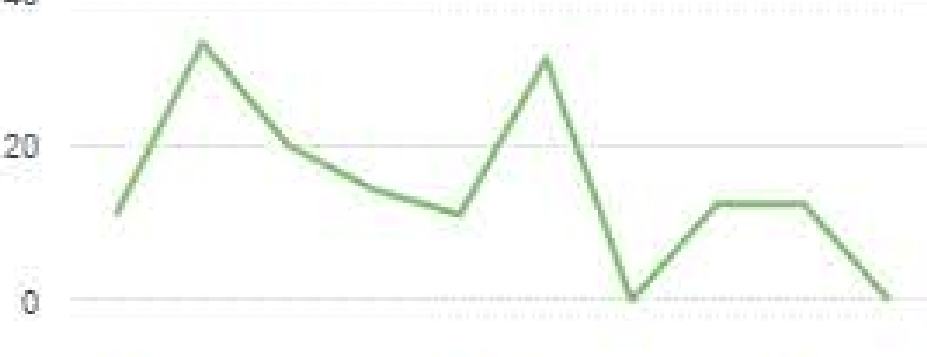

$2009 \quad 2011 \quad 2013 \quad 2015 \quad 2017$

- Show this widget

International journa of of
Socilotechnology and.

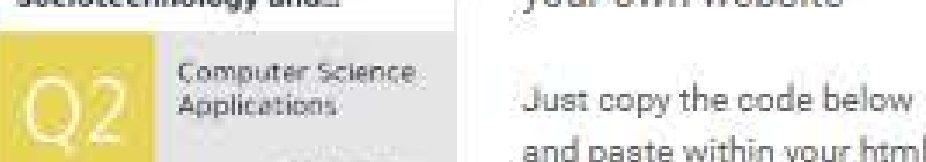

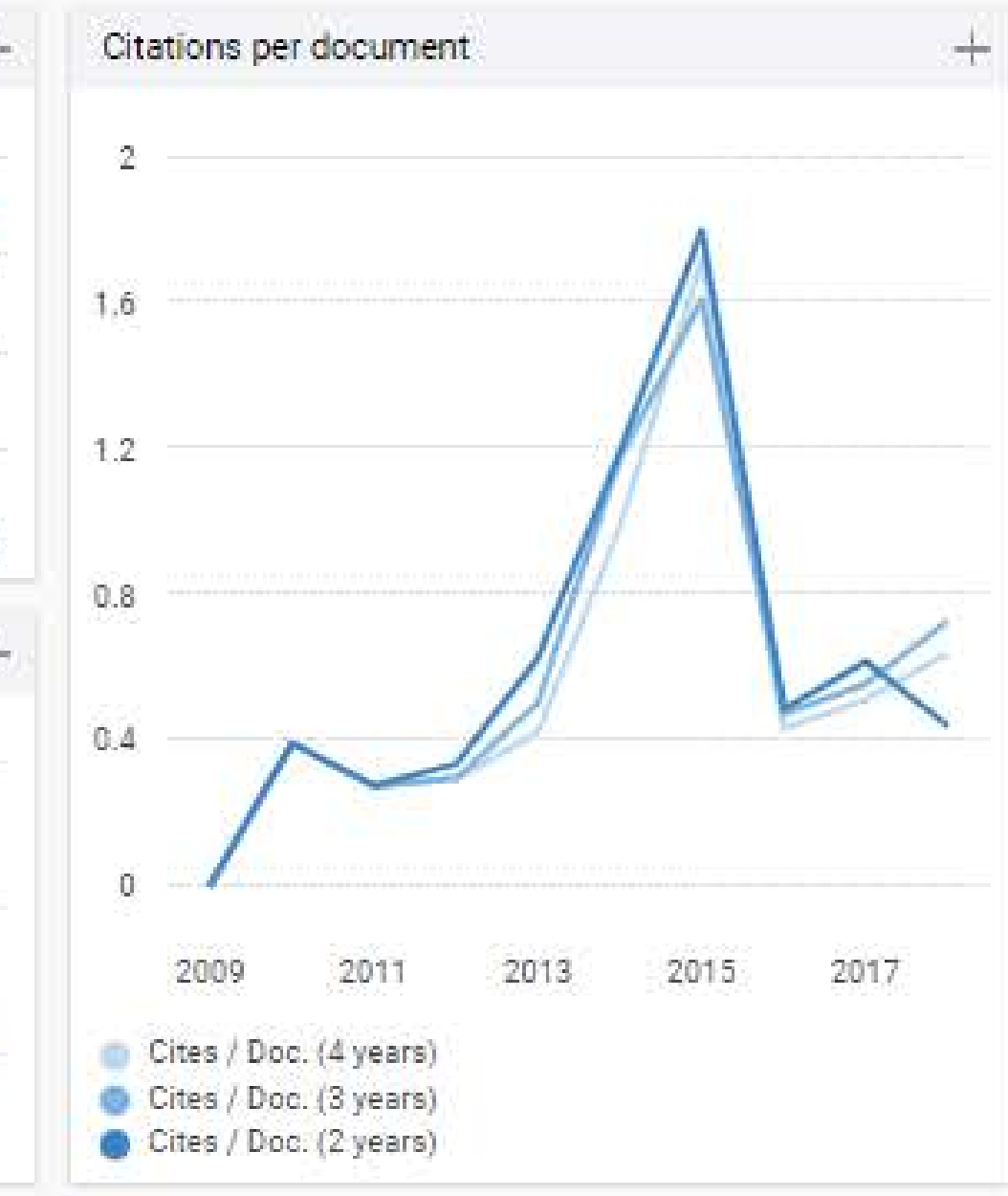

(1) IJKD_Copyright....docx ^ 1 Reviewer \#1.docx

1] Reviewer \#2.docx

山 Call-For-Articles.pdf

b) Masthead.pdf

山 The-Concept-of-Bi....pdf ^

山10.4018@USKD.20....pdf 、 


\section{International Journal of Sociotechnology and Knowledge}

Development

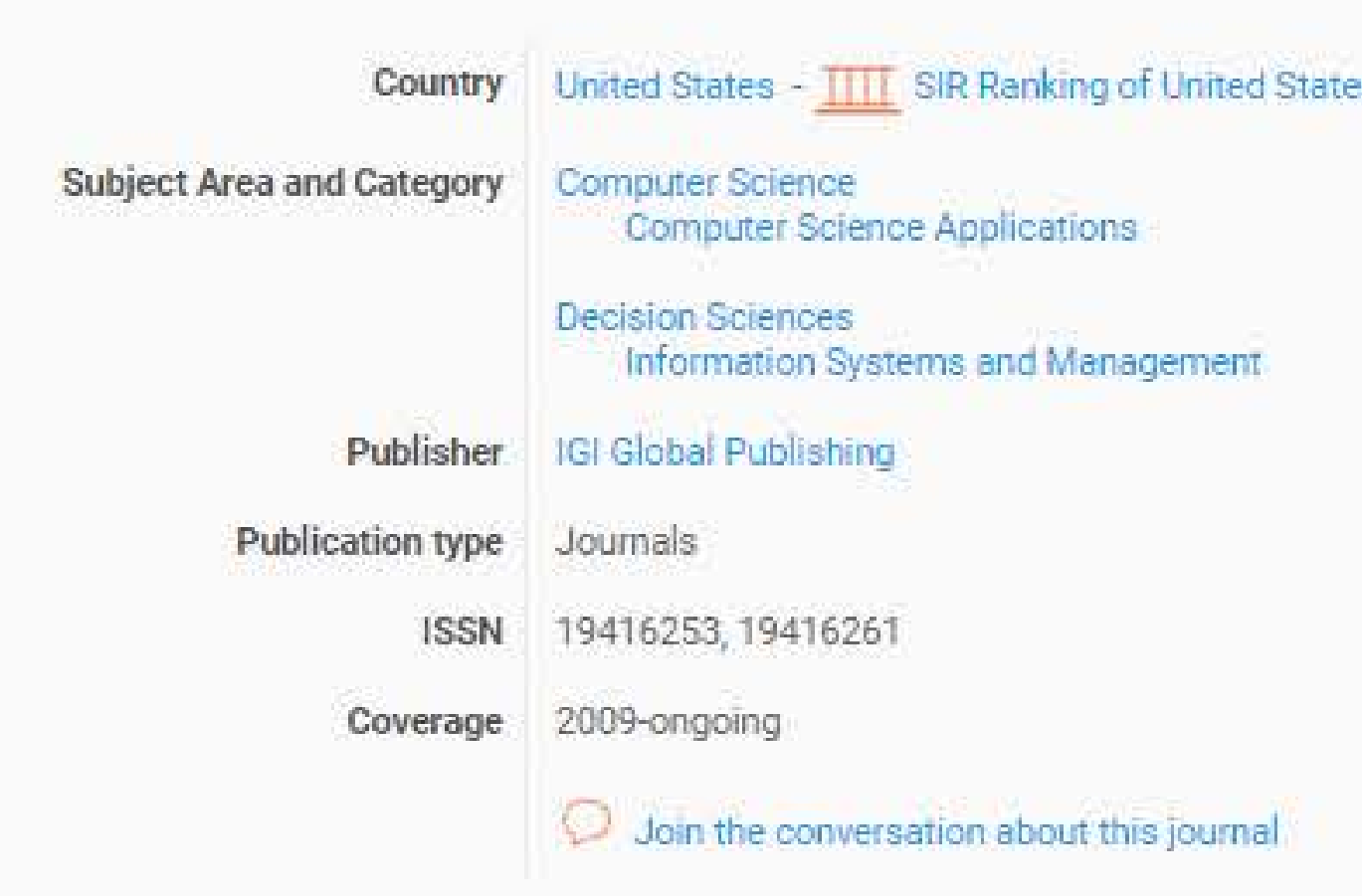

Quartiles

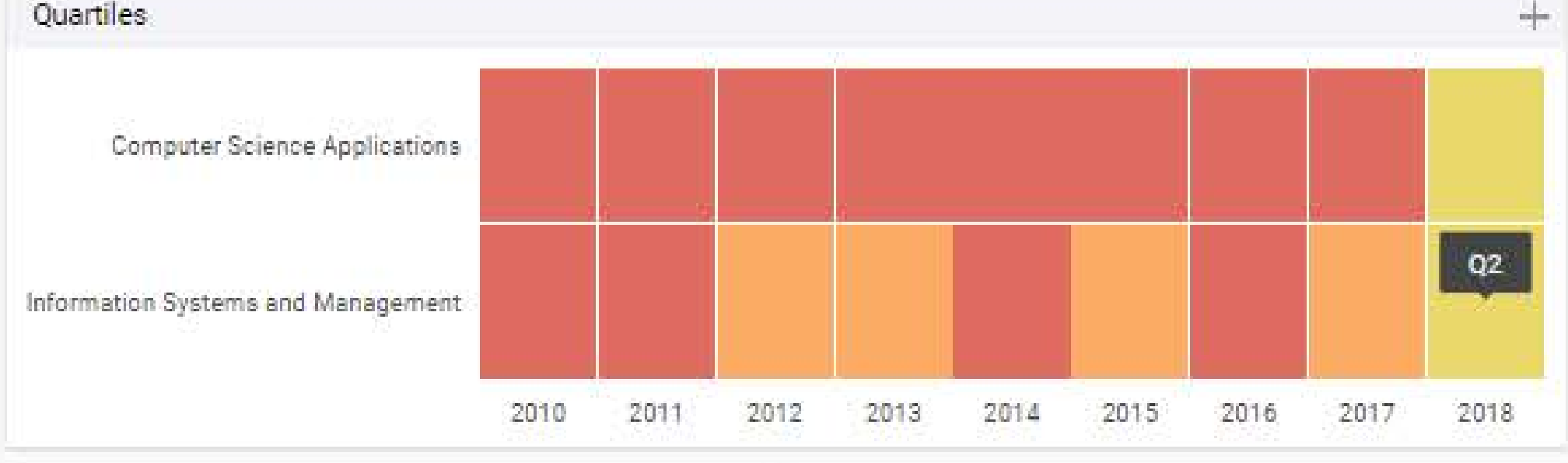

- Total Cites - Self-Cites

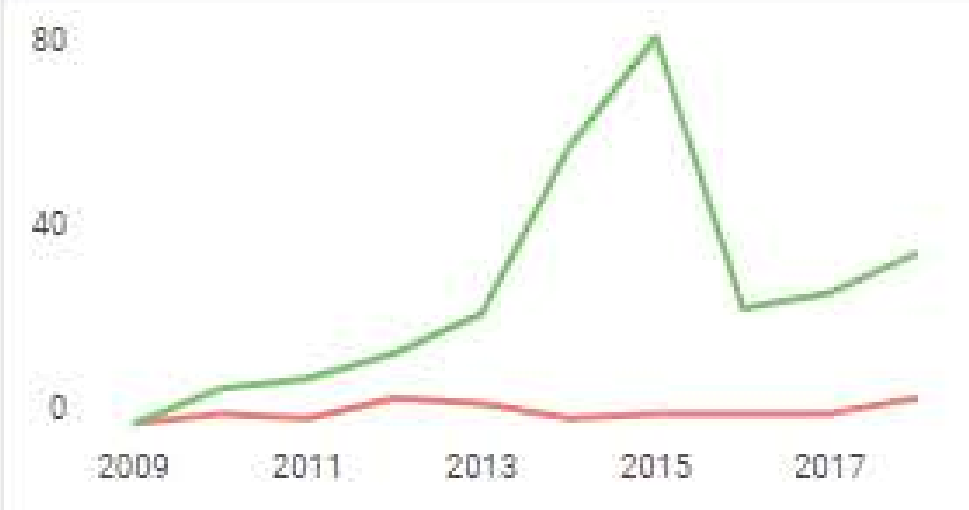

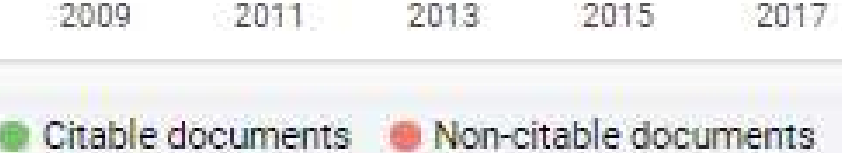

50

so
- External Cires per Doc $\bullet$ Cites per Doc
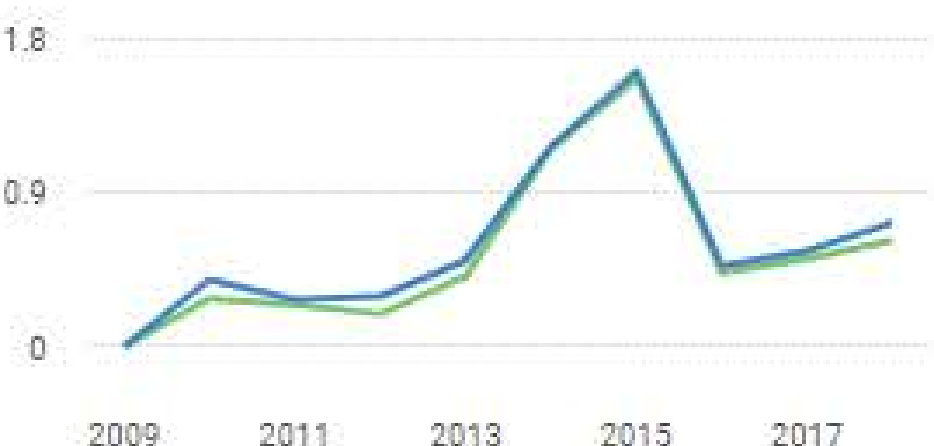

$2009 \quad 2011 \quad 2013 \quad 2015 \quad 2017$

Cited documents - Uncited documents

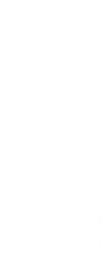

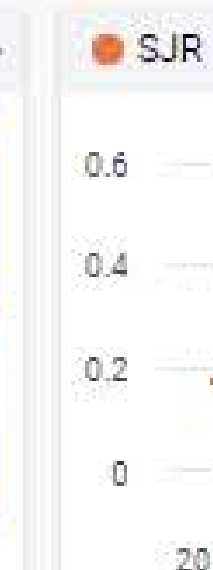

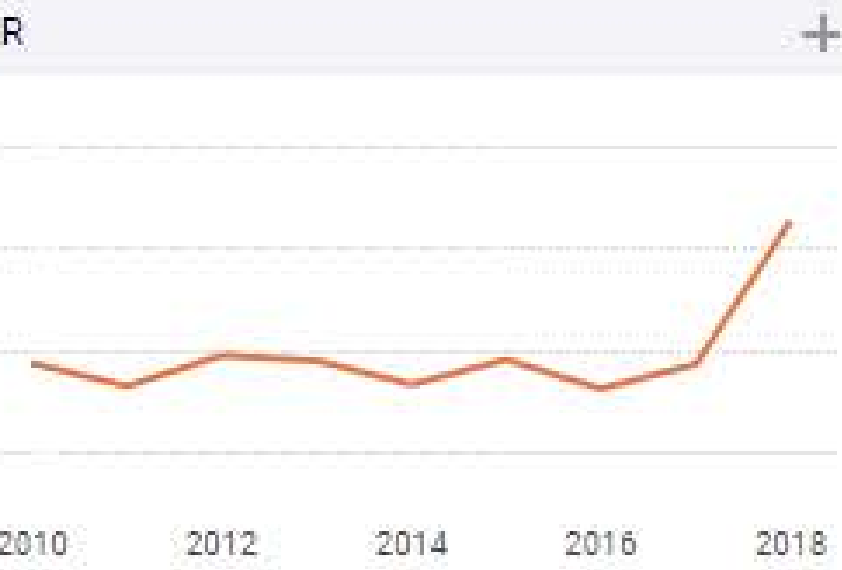

- \% intermational collaboration

40

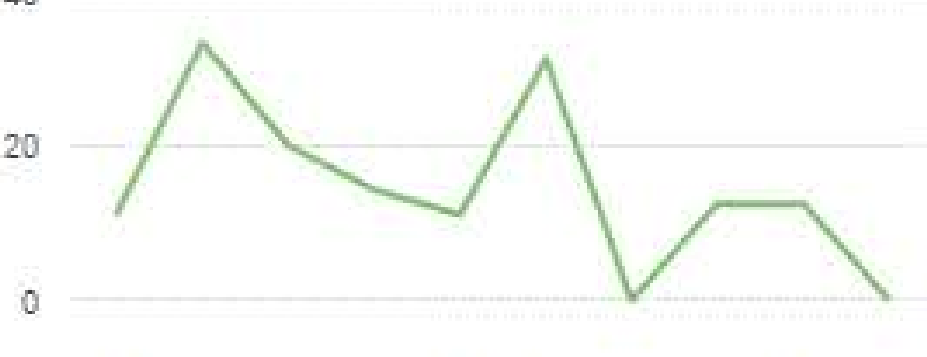

$2009 \quad 2011 \quad 2013 \quad 2015 \quad 2017$

- Show this widget

International journa of of
Socilotechnology and.

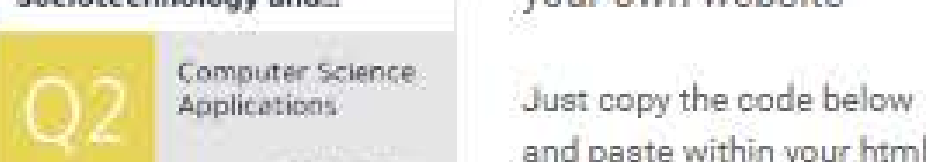

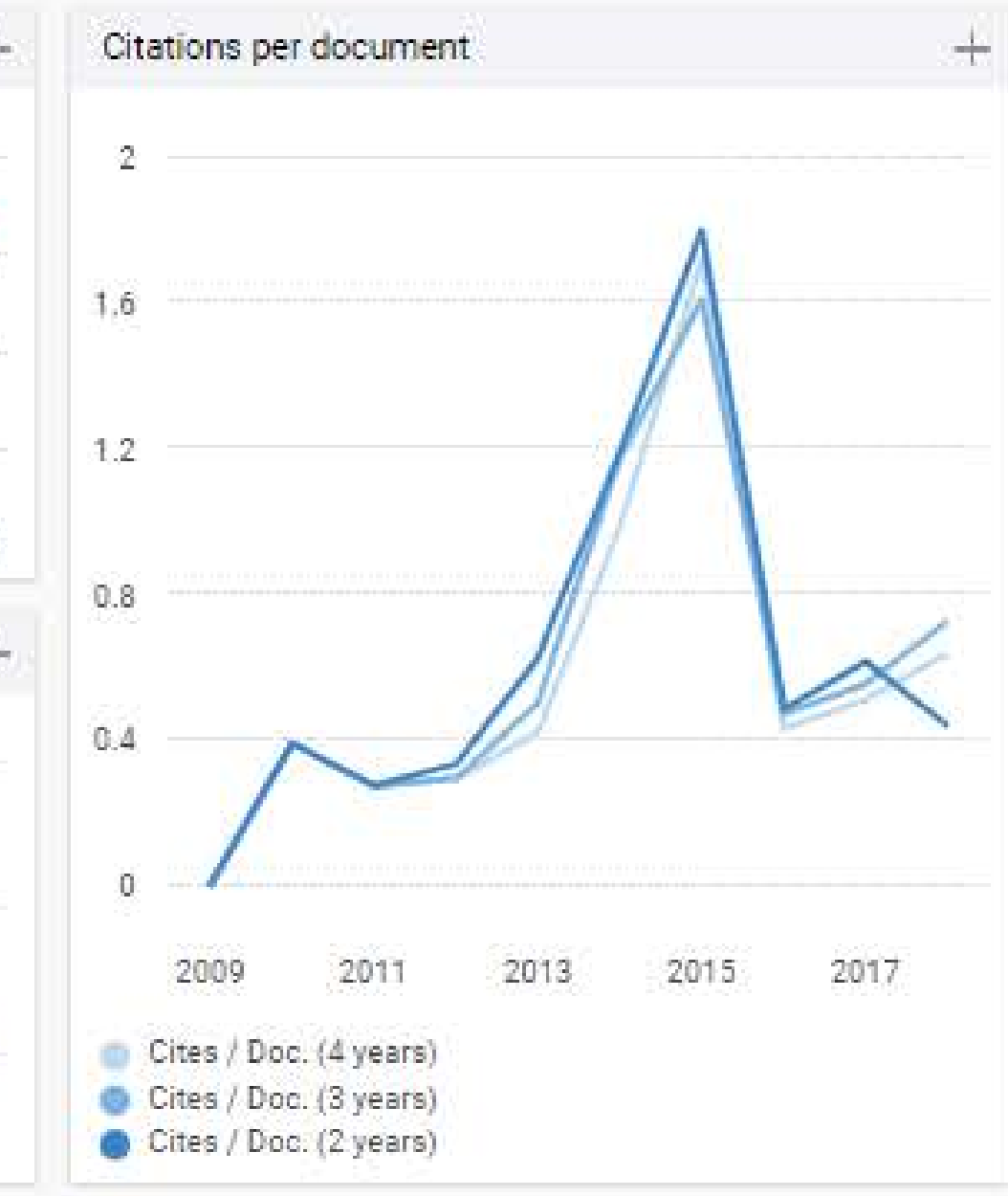

(1) IJKD_Copyright....docx ^ 1 Reviewer \#1.docx

1] Reviewer \#2.docx

山 Call-For-Articles.pdf

b) Masthead.pdf

山 The-Concept-of-Bi....pdf ^

山10.4018@USKD.20....pdf 、 


\section{International Journal of Sociotechnology and Knowledge Development}

Volume 11 • Issue 3 • July-September 2019 • ISSN: 1941-6253 • eISSN: 1941-6261

An official publication of the Information Resources Management Association

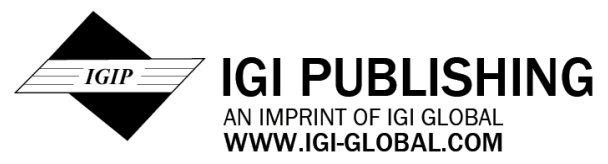

\section{EDITORS-IN-CHIEF}

Brian J. Galli, Long Island University, USA

Lincoln Christopher Wood, University of Otago, New Zealand

\section{EDITOR-IN-CHIEF EMERITUS}

Constance Kampf, Aarhus University, Denmark

José Luis Abdelnour Nocera, University of West London, Denmark

\section{ASSOCIATE EDITORS}

Ahmad Taher Azar, Benha University, Egypt Alex Ramirez, Carleton University, Canada Barbara Rita Barricelli, Università degli Studi di Milano, Italy Gilad Ariely, Interdisciplinary Center Herzliya (IDC), USA

\section{EDITORIAL REVIEW BOARD}

Abdul Samad Kazi, VTT-Technical Research Centre of Finland, Finland Ana Martins, University of KwaZulu-Natal, South Africa Benjamin Yeo, DePaul University, USA Brian Whitworth, Massey University, New Zealand Bruno Palvarini, Gippsland Grammar, Australia Colston Sanger, London South Bank University, UK Gillian Ragsdell, Loughborough University, UK Hanlie Smuts, University of Pretoria, South Africa Hilary Sarat-St Peter, Columbia College Chicago, USA Isa Jahnke, University of Missouri-Columbia, USA James Agee Jr, American University of Phnom Penh, Cambodia Jeremy Straub, North Dakota State University, USA John O’Neill, Chevron Chemical Company, USA Keith Patrick, University of Westminster, UK Lene Nielsen, IT University of Copenhagen, Denmark Leon A. Abdillah, Bina Darma University, Indonesia Liza Potts, Michigan State University, USA

María Rosalía Romagnano, Universidad Nacional de San Juan, Argentina Michael Kyazze, Nelson Mandela University, South Africa Michael W Kessinger, Morehead State University, USA Mihai Bîzoi, Valahia University Targoviste, Romania Munusamy Natarajan, Consultant (Library), India Nadim Akhtar Khan, University of Kashmir, India Natheer Khleaf Gharaibeh, Taibah University, Saudi Arabia Neeta Baporikar, Namibia University of Science and Technology, Namibia \& University of Pune, India Nyarwi Ahmad, University of Gadjah Mada Yogyakarta, Indonesia Prantosh Kumar Kumar Paul, Raiganj University, India Prathiba Nagabhushan, St Mary MacKillop College, Australia Steven Umbrello, Institute for Ethics and Emerging Technologies, University of Turin, Italy 


\section{Rankings}

Rankings are based on a 1 (lowest) through 8 (highest) scale.

Popularity of the subject $\quad 8$

Appropriateness for the journal $\quad 7$

Adequacy of literature review 5

Quality of research design 6

Adequacy of data analysis 6

Contributions to the literature 6

Legitimacy of conclusions 6

Practical/managerial significance 6

Clarity of presentation $\quad 7$

\section{Overall Evaluation}

Marginally publishable

\section{Recommendations for Review}

Manuscript requires major revisions from author(s)

Your Editorial Decision

Accept After Specified Revision

\section{Comments to the Author}

This is an interesting and considered article around a relevant topic on the use of sentiment analysis to inform the shaping and betterment of bureaucratic services reform. The applied use of sentiment analysis has potential merit in this regard.

There are several aspects of the paper which could be considerably strengthened, however, including more clarity in methods and results. Reviewer comments are provided separately for the consideration of the authors. 


\section{Rankings}

Rankings are based on a 1 (lowest) through 8 (highest) scale.

Popularity of the subject $\quad 7$

Appropriateness for the journal 8

Adequacy of literature review 6

Quality of research design 7

Adequacy of data analysis 6

Contributions to the literature 6

Legitimacy of conclusions 7

Practical/managerial significance 8

Clarity of presentation 8

\section{Overall Evaluation}

Definitely publishable

\section{Recommendations for Review}

Manuscript requires minor revisions from author(s)

Your Editorial Decision

Accept

\section{Comments to the Author}

in general, the topic of the paper is suitable for the Journal, it is mainly about applying the Big data for improving bureaucratic and public services, which is an important topic related to Sociotechnology field 